\title{
Do economic freedom, business experience, and firm size affect internationalization speed? Evidence from small firms in Chile, Colombia, and Peru
}

\author{
Christian Felzensztein ${ }^{1} \cdot$ George Saridakis $^{2} \cdot$ Bochra Idris $^{3} \cdot$ Gabriel P. Elizondo $^{4}$
}

Accepted: 13 July 2021 / Published online: 21 August 2021

(C) The Author(s) 2021

\begin{abstract}
This paper focuses on SMEs from the Latin American region and aims to build on existing literature on the emergence of the institution-based view in combination with the resource-based view. We contribute to existing literature by extending the application of the aforementioned theories to firms in three under-researched countries in this region. Specifically, we contribute to the extant literature by providing empirical insights on how home country-specific resources and firm-specific resources can affect the internationalization speed of SMEs in Latin American region. In order to achieve our objectives, we empirically examine the role of economic freedom (EF), prior business/international experience, and firm size on speed of internationalization. We use a dataset of Latin American SMEs, employing Poisson and negative binomial (NB) regression techniques. Our data cover three main Latin American Pacific Rim economies - Chile, Colombia, and Peru - with similar economic specializations, geographical borders, and economic growth dynamics. We find that (1) some parts of Economic Freedom Index (EFI) accelerate the speed of internationalization, whereas other areas slow it down or have no effect. Specifically, the closer to full EF the home country is in
\end{abstract}

George Saridakis

G.Saridakis@kent.ac.uk

Christian Felzensztein

cfelzens@clarkson.edu

Bochra Idris

b.idris@aston.ac.uk

Gabriel P. Elizondo

gabrielparraelizondo@gmail.com

1 Clarkson University, New York, USA

2 Kent Business School, University of Kent, Canterbury, Kent CT2 7FS, UK

3 Aston Business School, Aston University, Birmingham B4 7ER, UK

4 Formerly Universidad Adolfo Ibañez, Diagonal las Torres 2640, Peñalolén, Chile 
terms of regulations and government, the shorter the time to internationalize. (2) More experienced management teams are more likely to translate their knowledge into faster international market entry, but this pays off only for larger sized SMEs in contrast to smaller ones due to complementarities between managerial resources and physical, financial, and organizational resources. (3) Finally, industry, firm location, and country destination can only weakly explain the speed of internationalization. The findings add to the literature on SME internationalization in emerging markets and point towards potential policies to stimulate growth by SMEs in these markets.

\section{Resumen}

Este trabajo se focaliza en el estudio de pequeñas y medianas empresas (PYMES) de Latinoamérica y se construye basado en la literatura emergente de instituciones combinada con la de recursos. Contribuimos a esta literatura extendiéndola y aplicando a firmas basadas en tres países la región Latinoamericana. Específicamente contribuimos empíricamente a cómo recursos específicos de los países y de las firmas pueden afectar su internacionalización. También empíricamente examinamos el role de la libertad económica, experiencia internacional previa y el tamaño de las empresas para la rapidez de la internacionalización. Empleamos el método de Poisson y Regresiones de Binomios negativos. Los tres países estudiados: Chile, Colombia y Perú, miran hacia mercados de la zona del océano pacífico y tienen economías especializadas en recursos naturales y dinámicas de crecimiento similares. Los resultados demuestran: 1) algunas partes del índice que libertad económica aceleran la velocidad de internacionalización, en cambio otras partes la desaceleran o no tienen ningún efecto; Específicamente a mayor libertad económica de los países en términos de regulaciones y gobierno, menor será el tiempo de internacionalización de sus PYMES. 2) Equipos de gerencia con mayor experiencia tienden a trasladar su conocimiento más rápido para la entrada a mercados internacionales, aunque esto es mayormente en PYMES de mayor tamaño. 3) Finalmente, sector industrial, localización de la firma y país de destino, explica débilmente la velocidad de la internacionalización. Nuestros resultados aportan a la literatura de internacionalización de PYMES en mercados emergentes y señala potenciales políticas públicas para estimular su crecimiento.

Keywords Institutional theory $\cdot$ Resource-based view $\cdot$ Economic freedom $\cdot$ Business experience $\cdot$ Firm size $\cdot$ Internationalization speed $\cdot$ SMEs $\cdot$ Chile $\cdot$ Colombia $\cdot$ Peru

\section{Summary highlights}

Contribution: This paper presents new findings on international entrepreneurship (IE) by empirically examining how country-specific resources and firm-specific resources can affect the internationalization speed of small- and medium-sized firms in Latin America (namely, Chile, Colombia, and Peru). It proposes that when the SME's home country has strong market institutions, they create incentives to develop firm resources that allow them to internationalize earlier. Also, that prior business/international experience increases the likelihood of internationalization. Hence, this study contributes to the sparse, but growing, literature, on this subject related to small- and medium-sized enterprises (SMEs) operating in Latin America, a region that is still relatively 
under-researched. Moreover, by adopting the geographical relational approach proposed by Deng et al. (2020), we suggest that the geographical context of firms' internationalization does matter when investigating the internationalization process of firms from emerging economies.

Research questions/purpose: The aim of this paper is to examine how home-country institutions and international entrepreneurial capabilities that is previous international business experience can speed up the internationalization process of small firms operating in under-developed institutional environment.

Information/data: Data was collected through an online survey of SME managers (C-level and founders) that employee less than 250 employees, and 73 responses were received (60.3\% from Chile; $13.7 \%$ from Colombia; 26.03\% from Peru).

Results/findings: The paper shows that only some areas of the economics of freedom index might speed up internationalization. In particular, the results show that improvements in government size and regulations increase SMEs' internationalization speed. In addition, the results show that owner-managers' business/international experience reduces the time between start-up and the occurrence of internationalization. However, when prior business/international experience is interacted with firm size, we observe that prior business/international experience increases the time to internationalize for smaller firms compared to larger sized SMEs. In other words, prior experience pays off in larger sized SMEs more than in smaller ones.

Limitations: The sample size limits the predictive power of the econometric models that were employed. Specifically, having obtained responses mainly from firms from the more liberalized economies (Chile, Colombia, and Peru) did not allow for comparison with international entrepreneurs from much less liberalized countries (e.g., Argentina, Bolivia, Ecuador, and Venezuela).

Theoretical implications and recommendations: The paper offers new insights into the field of IE by looking at how home-country institutions and firm-specific resources can affect the internationalization speed of SMEs in Latin America. More specifically, the paper directly responds to the call regarding research on SMEs from the Latin American region, a relatively under-researched region with most of the existing research focusing on Mexico and Brazil. By doing so, the paper contributes to the literature by providing more insight regarding emerging markets' SME internationalization, considering the geographical context of emerging economies in which these firms operate. Additionally, the paper contributes to the existing literature by filling the gap regarding the role of institutional environment in emerging economies on the speed of internationalization, a gap that exists in the current literature since findings from developed economies do not apply to emerging markets.

Managerial and practical implications and recommendations: The results of the paper suggest that public programs or agencies should provide entrepreneurs with the means to help them rapidly scale up their business, and this involves using existing institutions. Companies in the Latin American region require assistance to commit to internationalization. The most important factor which appears to be helpful is the provision of training for owner-managers of small firms through government agencies. Additionally, existing SMEs with a minimum size should be connected to internationally experienced entrepreneurs who can assist these firms in speeding up their internationalization. This is important due to the rising relevance of international entrepreneurs in economic growth and the distinct behavior of internationalizing SMEs compared to more established large and multinational corporations. 
Recommendations for further research: Future research might advance this stream of research by considering less aggregated industry-level data. In particular, it would be useful to understand how more specific industry characteristics, such as domestic inter-firm rivalry and domestic buyer bargaining power, among others, affect internationalization speed and international intensity.

\section{Introduction}

Acceleration of the globalization process in the world economy (Jormanainen and Koveshnikov 2012; Paul and Gupta 2014) has rekindled the academic and policy interest in international entrepreneurship (IE). The existing research focuses mainly on new ventures from developed economies, primarily using a single theoretical perspective, including IE, international business (IB), or strategic management (SM) (Ramamurti 2004; Zahra 2004; Oviatt and McDougall 2005; Yamakawa et al. 2008; Jones et al. 2011). This paper, however, seeks to contribute to the sparse but growing literature on this subject related to small- and medium-sized enterprises (SMEs) operating in Latin America, a region that is still relatively under-researched (see review by Kiss et al. 2012). Previous literature indicates that the traditional theories of internationalization (such as the process model and the network perspective) may not adequately explain the internationalization process of SMEs (Mudalige et al. 2019). Hence, new empirical research on SME internationalization is needed (e.g., Andersson et al. 2014) to add to existing literature, which is mainly focused on SMEs from developed countries or on emerging markets such as China or Central and Eastern Europe (i.e., transition economies).

We argue that the Latin American region provides a unique and distinctive context for research. Being one of the richest regions compared to other regions in emerging economies and with improved stability as well as prospects of growth, it is increasingly becoming an attractive region for foreign investment from European countries (Malamud 2018). However, significant differences still exist in the region, especially in terms of how the institutional setting is structured. For example, the region can be broadly divided into two groups. The first group is considered to be an "open nationalism" and characterized by a horizontal government structure (such as Brazil, Chile, Peru, and Colombia). The second group can be described as a "closed nationalism," which relies on a hierarchical structure (such as Ecuador, Venezuela, and Cuba) (Carneiro and Brenes 2014; Malamud 2018).

To this end, a recent work by Rašković et al. (2020) calls for more "context-sensitive" research in the International Business (IB) field, and as Deng et al. (2020) suggest, with adopting a geographical relational approach in order to explain the internationalization of firms from specific and distinctive contexts of emerging economies. Firms, in emerging economies, are bounded to their home-country institutional settings, which arise from their "liability of emerginess" (Deng et al. 2020; Elia et al. 2020: p. 5), making them different to their counterparts from developed economies. Moreover, emerging and transition economies exhibit different institutional settings and development as there exists significant variety among these economies in terms of culture, history, and pathways to transformation (Chavance 2008). For example, Cuervo-Cazurra and Dau (2009: p. 481) suggest that the behavior 
of organizations from developing economies differ significantly to firms from transition economies because "the creation of capitalist system in transition economies" such as the creation of private enterprises resulted in a particular behavior. Hence, it has been suggested that when researching firms' internationalization from emerging economies, there is a need to understand the "spatial contexts" (Xu and Meyer 2013; Deng et al. 2020).

It has been suggested that the institutional environment and country-level differences may impact the international expansion of SMEs negatively, especially firms operating in emerging markets (Cuervo-Cazurra et al. 2017). Emerging economies may experience more fluctuations and regular changes in their institutions than developed economies. As a result, emerging economies have experienced increasing institutional development and evolution (e.g., Luo and Wang 2012; Brenes et al. 2018). In particular, our paper focuses on SMEs from Latin America for the following reasons. First, as existing research suggests, "emerging economies comprise a diverse range of countries in terms of both geography and level of development" (Kiss et al. 2012: p. 269), making this region a fruitful area of research. To elaborate this further, for example, the pro-market reforms "resulted in a deep transformation of the economy," which required the disassembling of state ownership and the creation of private enterprises (Cuervo-Cazurra and Dau 2009: p. 506). This process has started in the mid-1970s in Chile, in the early 1980s in China and in the late 1980s in Eastern European countries. Importantly, Chile is considered to be the first country to undertake market reforms in order to deal with economic crises. Thereafter, in the late 1980s, and early 1990s, other Latin American, Asian, and African countries started to apply similar reforms (Bruton 1998). Hence, studies based on regions' or country's development levels may be difficult to generalize (Kiss et al. 2012; Montocelli et al. 2017). Moreover, it has been argued that although similarities between emerging and transition economies exist, ignoring the context of these economies may lead to false assumptions and interpretations (c.f. Kostova and Hult 2016, for the comparison between transition and emerging economies).

Second, existing studies examining SMEs from emerging economies have mainly focused on the Asia-Pacific region (e.g., Zhang et al. 2017), or on transitional economies in Europe (Kiss et al. 2012). In contrast, Latin American countries have received little, but growing attention, with most research focusing on Brazil (the largest country in South America) (Azzi da Silva and da Rocha 2001; Ciravegna et al. 2014). Following the geographical relational approach proposed by Deng et al. (2020), we suggest that the geographical context of firms' internationalization does matter when investigating the internationalization process of firms from emerging economies. More specifically, we argue that countries such as Chile, Colombia, and Peru are also of great importance (Cyrino et al. 2010; Bianchi and Wickramasekera 2016), since their economies are also characterized by market liberalization, which depends to a great extent on entrepreneurship and private initiatives. Firms in emerging economies are "embedded in the context of social and institutional relations" (Deng et al. 2020: 59), and therefore contextuality, which implies that "economic agents are situated in contexts of social and institutional relations" (Bathelt and Gluckler 2003: p. 128), is of a great research importance. Along with other researchers (Chavance 2008; Kiss et al. 2012; Deng et al. 2020), we argue that the geographical context is important when studying firms' internationalization in emerging markets, and by doing so it can provide new evidence (possibly more refined) that can enable policy makers to craft 
enterprise policies to stimulate economic growth and sustain economic development in these economies (see Filatotchev et al. 2009; Mourougane 2012; Bianchi and Wickramasekera 2016)

Although countries in Central and Eastern Europe are moving towards a market economy, these economies actually transitioned from different "starting points and at a varying rates" (Kiss et al. 2012: p. 56). In Latin America, similar heterogeneity of these emerging economies can also be observed. For example, although Chile and Peru received similar institutional changes because of their increasing involvement in international trade agreements (Pino et al. 2019), where a high percentage of their exports originates from natural resources (Brache and Flezensztein 2019), Chile is being perceived as the most open economy in the Latin American region due to the formation of liberal policies to foster free international trade. Moreover, politically, the region is becoming "polarized insofar" as some countries are becoming democratic and others are not. For instance, Chile, Colombia, and Peru represent free market economies while Ecuador, Argentina, and Venezuela tend to show economic protectionism; hence, the former countries are growing faster than the latter ones (Carneiro and Brenes 2014: p. 832). It is therefore interesting from an academic and a policy perspective to examine how quickly firms in these regions are expanding to international markets (Bianchi and Wickramasekera 2016).

Moreover, the internationalization process of enterprises from emerging economies has challenged existing theories and assumptions about internationalization (see Hong et al. 2015). One may argue that SMEs "are not just small variants on large MNEs" (Knight and Liesch 2016: p. 95) as they are structured in a different way and behave differently from each other. For instance, although SMEs are restricted by resource constraints (i.e., the "liability of smallness") and they do not possess the appropriate advantages such as technological capabilities and a strong brand name (Buckley et al. 2007), they are still capable of conducting international business activities (Puthusserry et al. 2020). It has been suggested that MNEs' competencies arise from the level of control through ownership whereas SMEs' competitive advantages lay on the flexibility they offer and their ability to respond to changes in the surrounding environment (Lu and Beamish 2001).

Also, SMEs operating in under-developed institutional environments may face additional challenges than their counterparts in developing countries. For example, it has been found that firms in Latin America may rely more on their personal networks since there is low trust in the efficiency of their legal system (see, for example, Ciravegna et al. 2014). Although similar findings come from other emerging economies (Estrin and Prevezer 2011), there exists differences among them due to cultural differences and individuals' attitude and perceptions (Amoros and Bosma 2014). For example, Chinese SMEs tend to rely heavily on their government when seeking international business opportunities, since political ties matter more than personal ties in China (Zhang et al. 2016).

Moreover, studies on the factors that affect SMEs' internationalization for firms in Latin America show that in Chile, for example, the internationalization is prompted by participations in export committees, while the internationalization process of firms from the whole region appears to be a planned process with the firms to be "more likely to be born regional than born global" (Lopez et al. 2009; Kiss et al. 2012: p. 274). However, the internationalization speed for firms from a transition economy such as the 
Czech Republic, for example, is motivated by a shared language and diverse geographical networks. It should be mentioned that findings regarding firm's level resources on the internationalization speed for firms in emerging economies are mixed. For example, Wood et al. (2011) find that there is no association between entrepreneurs' foreign education and the internationalization speed for firms in India, China, Mexico, and South Africa. However, previous international work experience is found to have a positive effect on the speed of internationalization, which is contrary to findings from Poland (Nowiński and Rialp 2013) and Vietnam (Thai and Chong 2008).

Firms' resources and capabilities in emerging markets, such as Latin America and China, are derived from managerial assets and redevelopment of resources (Luo 2003; Brenes et al. 2014), while the country-specific resources are derived from its institutional environment (Elango and Pattnaik 2007). It can be therefore argued that the internationalization process of SMEs from these regions may be based on a combination of home country-specific resources and firm-specific resources. It has been suggested that firms' internationalization is generally a result of a combination of macro-level institutions and firms' specific resources (micro-level) (Deng et al. 2018). Recently, Deng and Zhang (2018) argue that research that focuses on macro-level factors only may provide an unclear picture of how the internal factors of SMEs may either assist or constraint their internationalization prospect. Their results show that different firm-specific resources (e.g., manager's experience) play a significant role in SME internationalization from China, while a low quality of home-country institutions encourages firms to internationalize. Hence, our aim in this paper is to extend our knowledge by determining whether or not such findings are also apparent in Latin American economies. To do this, we empirically examine whether the quality of home-country institutions affects the internationalization speed of SMEs in Latin America, and whether previous international/business experience of the decision-maker accelerates the internationalization process.

To this end, we aim to build on existing literature on the emergence of an institution-based view of strategy in combination with the resource-based view to investigate their link to internationalization speed. The increased use of the institution-based view as an influential tool calls for more research in order to examine the complex and frequent changes in the firm-environment relationship in emerging markets (Gao et al. 2010). According to Wang et al. (2012: p. 657), these two theoretical perspectives are complementary to each other, although the factors associated with each perspective are often "competing." Hence, this integrative mechanism is specifically suitable for examining firms' expansion from emerging markets. Using the institutional theory and the resource-based view theory jointly, we are able to contribute to existing and current literature (e.g., Peng 2003; Wang et al. 2012) by providing new empirical insights regarding how these two country-specific resources and firm-specific resources can affect the internationalization speed of SMEs in Latin America.

Specifically, our research considers three Latin American economies, that is, Chile, Colombia and Peru. Previous research shows that SMEs operating in business environment with limited domestic market tend to expand their businesses aboard (Javalgi et al. 2011), and emphasize the role of institutions in export performance, specifically for small firms (e.g., Ketkar and Acs 2013). It has been suggested that "Latin American economies" may not be treated as a "homogeneous group" (Bianchi et al. 2018: p. 202) since a number of differences exists among them (Acquaah 2007). For example, according to the Global Competitiveness Report (GCR 2017), Chile is ranked 33, and although it has a small market size, it is considered the most open economy in the 
region (Bianchi et al. 2018). Colombia and Peru, on the other hand, are ranked 66 and 72, respectively (GCR 2017). ${ }^{1}$ The general business environment for entrepreneurs in this region is still considered to be the main challenge. Firms in these countries, similar to those from other emerging markets, have to overcome a significant number of barriers to increase their competitive advantage because of, for example, the undeveloped infrastructure, limited supply of trained employees, and the instability of the economic and political factors in the region (Brenes and Haar 2012).

Although previous research has increased our knowledge on SME internationalization processes, there is still limited knowledge regarding the role of institutions on firms' internationalization speed in emerging economies (e.g., Yamakawa et al. 2013). In particular, IE research introduced the concept and measurement of internationalization speed, defined as the time passed between the year of foundation of the firm and the year of its first foreign sales (Zahra and George 2002). However, we still need to better understand internationalization speed, both conceptually (Casillas and Acedo 2013; Chetty et al. 2014) and empirically (Casillas and Moreno-Menéndez 2014).

For example, Laufs and Schwens (2014) suggest that there is a gap in the literature with respect to the role of institutional environment in affecting SME entry mode decisions. In addition, Zhang et al. (2017) have recently argued that research on entrepreneurship in the international context has ignored the role of institutional environment. We therefore directly respond to the call for further research about the effect of firms' home country on the speed of internationalization (e.g., Laufs and Schwens 2014; Hitt et al. 2016; Knight and Liesch 2016), since research findings from developed economies are not necessarily transferable to emerging economies (Zander et al. 2015). We also respond to the call from a number of scholars for more research that can add to our knowledge and understanding of SMEs from emerging markets, especially from Latin America (e.g., Cardoza et al. 2016).

In this paper, we add to the existing literature that explores the role of the home country's institutional context as a provider of incentives for SMEs to accelerate their readiness for international markets (see Casillas and Acedo 2013; Casillas and Moreno-Menéndez 2014; Hilmersson and Johanson 2016). Most of the existing empirical research focuses mainly either on large MNEs from developed economies (e.g., Arregle et al. 2013) or from emerging economies like China (e.g., Sun et al. 2015) overlooking contexts where SMEs prevail (Kiss et al. 2012) and institutional voidsthe lack of institutions to foster market development — are ubiquitous (Doh et al. 2017; Gil-Barragan and López-Sánchez 2021). We argue that internationalization can help SMEs to improve their competitiveness and strategic position and to build resilience to withstand economic shocks which threaten their growth and lifespan prospects (see Herrera Bernal et al. 2002; Ferreira and Saridakis 2017).

By carrying out a survey in three Latin American Pacific Rim countries (Chile, Colombia, and Peru) and using a multi-step protocol (Dillman 2007), we empirically examine how home country institutions influence the internationalization speed of Latin American Pacific Rim SMEs. In our specification, we also control for human capital through managerial experience, since this may affect the relationship between home market institutions and internationalization speed. For example, it has recently been argued that economic freedom (EF) affects human capital investment (see

\footnotetext{
${ }^{1}$ More information regarding the similarities and differences of these three countries is provided in the methodology section.
} 
Feldmann 2017). In addition, our model allows prior business/international experience to be moderated by firm size. Finally, we further control for industry and location. Our paper updates previous important but limited research focusing on emerging economies (e.g., Wright et al. 2005; da Rocha et al. 2012; Ciravegna et al. 2014; Bianchi et al. 2017; Nuhu et al. 2021) and contributes towards our understanding of the internationalization process of the SMEs in these countries.

Overall, our results show that the speed of internationalization accelerates when the SME's home country has strong market institutions, because they create incentives to develop firm resources that allow them to internationalize earlier. Hence, we contribute to the empirical advancement of IE literature by examining an under-researched set of countries (Cuervo-Cazurra and Dau 2009), adding variability in home country institutional contexts and adopting a micro-econometric approach to understand the speed of SME internationalization over time. Secondly, we find that prior business/international experience increases the likelihood of internationalization. It can be argued, for example, that more experienced management teams are more likely to translate their knowledge and skills into faster international market entry. Finally, we suggest that prior business/ international experience pays off only for larger sized SMEs, in contrast to smaller ones. This is due to likely complementarities between managerial resources and physical, financial, and organizational resources. Therefore, we also reconcile different theoretical propositions on the effect of managerial experience and size on SME internationalization (see also Arte 2017). For example, previous business/international experience allow firms to overcome the liability of foreignness associated with internationalization.

Our results have important implications for SME owner-managers and policy-makers in emerging markets. Firstly, our results show that not all components of economic freedom affect the speed of internationalization in the same way. In particular, government size and regulation are found to significantly reduce the time between inception and internationalization activity, whereas access to sound money, which captures macroeconomic and price stability, decelerates internationalization speed. Secondly, previous managerial and internationalization experience are more likely to be associated with faster international market entry, especially for larger sized SMEs. Participating in internationalization programs and forming collaborations with internationally experienced SMEs may help the latter to climb the internationalization ladder faster and expand their operations to foreign markets.

The paper is organized as follows. Firstly, we provide a brief overview of the literature and derive our hypotheses. Secondly, we describe the sampling approach and the survey data used. Thirdly, we explain the data, measures of the key variables, and methodology. Fourthly, we present our conceptual and empirical models. Fifthly, we present the estimation results. In the final section, we discuss the results, followed by a summary and recommendations for further research.

\section{Background and hypotheses derivation}

\section{Resource-based view theory and institutional theory}

Historically, the Resource-Based View theory of the firm-RBV-(Barney 1991) has been considered to be one of the key theories in entrepreneurship research and it has 
become a widely used approach to understand firm's internationalization process making a significant contribution to IE field (Bruton et al. 2010; Peiris et al. 2012). The RBV considers the firm's valuable and rare resources and capabilities as foundation of sustainable competitive advantages (Wernerfelt 1984; Barney 1991; Hollender et al. 2017). It has been suggested that resources include tangible and intangible strengths or weakness tied to the firm (Wernerfelt 1984). Capabilities, on the other hand, are also considered firm-specific abilities that combine firm resources in order to achieve a desired outcome (Amit and Schoemaker 1993). Therefore, capabilities include a combination of knowledge and skills that are embedded in the firm processes and routines with the purpose to create value for the firm either directly or indirectly (Grant 1996). According to Hollender et al. (2017), resources and capabilities enable firms to implement strategies with better efficiency. However, a central question proposed in previous studies regarding the source of these resources and capabilities (Ngo et al. 2016). Ethiraj et al. (2005) argued that these capabilities can be the results of previous and accumulated experience embedded in routines and learning by doing. Alternatively, it can be viewed as a result of a careful investment decision in the firm's systems and organizational structure with the aim of improving the firm's practices. In other words, it is the previous experience of the owner-manager of the firm that matters. In this paper, we examine whether the previous business/international experience of the key decision maker of the firm leads to substantial competitive advantage which in turn speeds up the internationalization process, as it has been suggested in the RBV.

On the other hand, it has been indicated that while resources are critical for the firm, it has become increasingly clear that issues such as legal and economic incentives can impact entrepreneurial success (Baumol et al. 2009). Institutional theory provides a theoretical lens which researchers can identify and investigate these issues (Bruton et al. 2010). According to North (1990), institutions can be defined as the "rule of the game" in a society. Institutions can be either formal — such as rules that human beings develop —or informal, such as codes of behavior. DiMaggio and Powell (1983) categorized institutional "isomorphism" into three types which are "coercive, mimetic, and normative" (Azman et al. 2018). It has been implied that coercive pressure comes from government policies and regulations, as well from industrial groups and professional networks. For example, when a legal restriction exists in the home country, the firm's international expansion may be affected either positively or negatively (Daviset al., 2000). Hence, firms might engage in active strategies (Huang et al. 2017) such as going abroad in order to reduce the effect of domestic institutional restrictions (Stoian and Mohr 2016) as a response to institutional complexity (Greenwood et al. 2011). In this paper, we apply the institutional theory, more specifically the coercive type that arises from government regulations and policies in order to examine whether home country's institutions affect the internationalization speed of SMEs in Latin America. Since the internationalization process of enterprises, and especially those in emerging economies, has challenged existing theories, scholars and researchers recently argued that different internationalization trajectories can be explained by institutional conditions including both home and host country institutions (e.g., Mike et al. 2009; Wang et al. 2012). Hence, previous limited studies recognized the joint role of the RBV and institutional factors on firm's performance and competitive advantages (Wang et al. 2012). 
This paper uses the RBV and the institutional theory as it has been indicated that these two theories can complement one another in explaining SME internationalization since differences in firm resources may also influence firm's ability to respond to regulation pressures (Hong et al. 2015). By adopting the institutional theory (home country-specific resources) and the resource-based view theory (firm-specific resources), we aim to examine how home country institutions and international entrepreneurial capabilities, that is previous international business experience, can speed up the internationalization process of small firms operating in under-developed institutional environment. More specifically, our research questions are as follows: (a) does the quality of home-country institutions affect the internationalization speed of SMEs in Latin America? (b) Does the international/business experience of the decision maker influence the internationalization speed? And (c) does the size of the firm moderate the experience-internationalization relationship?

\section{The speed of internationalization}

Three main dimensions of the internationalization process can be identified. Firstly, the degree of internationalization involves (1) the scale and (2) the scope of internationalization. The scale of internationalization refers to the dependence on international sales and suggests a decreasing reliance on domestic sales; it can determine a firm's international exposure. The scope of internationalization refers to the number of markets in which the firm operates (Hilmersson 2014). Another dimension of the internationalization process is (3) the speed of internationalization; this can be defined as the rate at which firms spread their international activities (Hilmersson 2014). Over the past few years, there has been growing attention to time-based competition in international markets (Stalk and Hout 1990). Hence, interest in the speed of internationalization has grown significantly (e.g., Hilmersson and Johanson 2016; Knight and Liesch 2016; Kabongo and Okpara 2019; Yang et al. 2020).

The concept of speed of internationalization has its roots in international entrepreneurship research (Zahra and George 2002; Oviatt and McDougall 2005). Scholars have started a new research agenda on IE, which was initially considered the comparison of entrepreneurial behavior across nations and cultures with organizational behavior that extends across national borders and is entrepreneurial (Baker et al. 2005). In particular, internationalization of new ventures from emerging economies (IEE) (Yiu et al. 2007; Peng et al. 2008) has gained attention from scholars worldwide, increasing the scope of IE as a research field (Kiss et al. 2012). The concept of IE, therefore, has evolved from its initial conceptionwhere internationalization was examined as an incremental and slow process (Johanson and Vahlne 1977) - to a broader notion of "the discovery, enactment, evaluation, and exploitation of opportunities - across national borders - to create future goods and services" (Oviatt and McDougall 2005: p. 540). This international entrepreneurship approach coined the internationalization speed concept, which is defined as the time between a firm's inception and its first international market entry (e.g., Reuber and Fischer 1997; Musteen et al. 2010).

Recently, and as indicated by Hilmersson and Johanson (2016), the speed at which SMEs have expanded their operations abroad has received a great attention from different researchers (Casillas and Moreno-Menéndez 2014) and has become the central aspect of the debate on whether the traditional models of internationalization are valid. Several studies show that firms are internationalizing rapidly (McDougall 
et al. 1994; Oviatt and McDougall 1994, 2005; Coviello 2006) and that some firms choose to internationalize from their inception (Oviatt and McDougall 1994; Chetty and Campbell-Hunt 2004; Crick 2009). Existing research shows that firms can gain first mover advantage by being the first occupant of a market (Grant 2010). When firms internationalize at a higher speed, they will gain access to resources and it is therefore likely that greater opportunities over their competitors can emerge. Sapienza et al. (2006) suggest that when firms internationalize at a later stage since their inception, they are more likely to have routines that can hinder their internationalization process. However, when a firm internationalizes at a younger age, it is more likely to possess structural advantages than older firms; the younger the firm is, the faster it can adapt to a changing environment and adjust its strategies and routines (Schueffel et al. 2011). Autio et al. (2000) found that young internationalizing firms have "learning advantages of newness" (Sapienza et al. 2006: p. 996).

One of the major theoretical implications of high internationalization speed is that it challenges the traditional models of incremental international expansion. For example, the process theory of internationalization developed by Johanson and Vahlne (Johanson and Vahlne 1977, 1990) explains why firms undertake internationalization at later stages in their development and why the process is generally slow and incremental. However, scholars at the intersection of entrepreneurship and internationalization have criticized the process theory of internationalization since it fails to explain firms that go international soon after their inception (Oviatt and McDougall 1994).

As a result, a new venture theory of internationalization has emerged, which implies that some entrepreneurs have the required skills and knowledge which allow them to explore and exploit foreign market opportunities at an early stage. On the one hand, researchers who agree with the process model of internationalization view the firm as seeking to avoid uncertainty and risk while, at the same time, seeking growth. These firms will grow in an incremental way by entering foreign markets gradually. On the other hand, researchers who oppose this view and agree with the new venture model of internationalization view growth opportunities as the key driver of internationalization. The new venture model of internationalization emphasizes the positive outcomes generated through early internationalization.

Therefore, the question is what explains firms' variation in speed of internationalization. Strategy research, for example, has argued that institutional factors provide incentives that affect the competitiveness of emerging economy firms and thus the scope of their international footprint (e.g., Cuervo-Cazurra and Genc 2008; Ramamurti and Singh 2009; Khoury and Peng 2011; Hoskisson et al. 2013; Yamakawa et al. 2013). For example, Hitt et al. (2016) find that the quality of the home country institutions affects firms' early and fast internationalization in significant ways. Relatedly, a multi-country sample of transition economies has provided evidence of the effect of home country institutions on export growth (Shinkle and Kriauciunas 2010). Expanding on this stream of literature, we can expect that institutional development positively affects the internationalization speed of firms from emerging economies.

\section{Home country-specific resources: Home country institutions}

Institutional theory has been widely used to explain firms' strategies to enter and engage in foreign market activities, especially in the emerging market context (Meyer 
and Peng 2005; Lindsay et al. 2017). Institutions consist of external factors that affect the mechanism of the market. North (1990) highlights the role of formal and informal institutions in firms. Formal institutions consist of the social, economic, and political factors and are generally known as the "rules of law." In contrast, informal institutions consist of culture, relationships, and family (Chen et al. 2009). According to Meyer et al. (2009), in emerging economies, institutions are more visible and dominant than those in developed countries. It has been suggested that in emerging markets, the central and local governments are more proactive and larger than institutions in developed markets (Peng et al. 2008). Therefore, institutional theory can be considered an appropriate application to examine the behavior of firms from these markets (Boehe et al. 2016).

Previous studies implied that home country institutions are important for SMEs' internationalization, either in terms of government assistance (Durmuşoğlu et al. 2012; Crick and Lindsay 2015) or in terms of how relationships with home country suppliers influence the internationalization process and growth of SMEs. The theoretical literature suggests that early and accelerated international market entry can be enhanced by stronger institutional development in terms of market internationalization and competition in the country of origin (Madsen and Servais 1997; Oviatt and McDougall 2005; Gao et al. 2010). In part, home market institutions can have important micro-economic effects-i.e., fiercer competition through reduced barriers to market entry and curbing market power. Specifically, the combination of the following mechanisms likely increase competitive intensity: (a) opening home markets for imports by lowering import taxes and non-tariff barriers to imports; (b) opening home markets for inward foreign direct investment (FDI) by foreign multinationals by reducing restrictions on inward FDI; and (c) increasing the number of private players, as opposed to state or private monopolies, by privatization and competition policy, among other mechanisms (Del Sol and Kogan 2007). As a result, imports and FDI increase the penetration of foreign products in the home market, and competition regulations seek to ensure rivalry among domestic and foreign firms. Accordingly, the institutional environment provides incentives for founders to develop new businesses that are more likely to survive in a fierce competitive environment. Thus, firms in such environments need to have stronger competitive advantages from inception.

Moreover, an increasingly open international trading environment fosters greater specialization and thus more rapid capture of increasingly transitory competitive advantages (Barney 2001). Correspondingly, internationalization theory suggests that strong competitive advantages explain international market entry (Rugman 1981). For instance, the RBV argues that firms can internalize some portions of their value chain in order to gain competitive advantages (Zhang et al. 2017). Laantia et al. (2007) emphasize the role of resources and capabilities of the firm and its owner in enabling the firm to undertake early internationalization. However, Wang et al. (2012) argue that since firms differ in their competencies to take advantage of the benefits from changes in institutions, the impact of these changes on firm's internationalization process may differ according to firms' competencies and characteristics. Also, Kirzner (1997) suggests that the level of competition in the country depends on its EF level which, in turn, can enable entrepreneurs to penetrate new markets and exploit opportunities. Hence, although firms might function in similar institutional settings, the influence of these institutions will depend to a great extent on firm's characteristics and capabilities (Mudambi and Navarra 2002).

Hitt et al. (2004) suggest that institutional factors can have a greater effect on shaping the economic activities of a firm. For example, EF has been used to assess the freedom 
which individuals have to engage in transactions. Previous studies, such as that by Karabegovic and McMahon (2005), have linked the level of economic freedom in a region to its economic growth and other performance outcomes. Moreover, the level of economic freedom has been linked to the level of entrepreneurial activities (Dickson et al. 2013). It is generally assumed that the level of market freedom in the home country of the SME can affect the timing and the decision to internationalize in different ways (e.g., an SME can have greater capacity of resources when there is a low economic burden placed by the government, increasing its probability of internationalization).

According to Ramamurti and Doh (2004), most developed countries enjoy a strong institutional environment compared to emerging economies. It is suggested that SMEs located in developing economies suffer from institutional voids, where the laws and regulations can be insufficient (Mesquita and Lazzarini 2008). Therefore, SMEs' internationalization from these economies tends to be negatively affected by the low quality of their home institutions (LiPuma et al. 2013). In emerging markets, continuous institutional voids, such as the lack of finance, regulation uncertainty, and corruption in the system present an increasing challenge for firms to operate in efficient ways (Tang et al. 2014; Stoian and Mohr 2016). Similar to what has been found in other emerging markets such as China or Russia, the major obstacle for Latin American firms' growth and development is the weak institutional settings that characterize these markets (Calvo et al. 2006; Chan et al. 2008). For example, business relations in Latin America tend to be based on personal contacts (Cardoza et al. 2016). Firms in emerging economies adopt an international expansion strategy to overcome institutional pressures (Deng and Zhang 2018). Therefore, it has been argued that a low quality of home-country institutions acts as a driver for firms to internationalize. For example, Narooz and Child (2017) find that SMEs in Egypt have limited knowledge of the available opportunities for internationalization due to inadequate support from home country institutions. In contrast, SMEs in developed economies tend to enjoy a wide range of support, and accessible and efficient sources of external support (Child et al. 2017). More recently, Deng and Zhang (2018) found that the quality of home-country institutions is negatively related to the probability of Chinese SME internationalization in the initial phase and positively related to their overseas sales growth.

Likewise, prior empirical research shows that firms originating in countries with strong market institutions tend to be more competitive abroad, particularly in countries with less competitive markets (Del Sol and Kogan 2007). SMEs operating in developing countries, however, are likely to suffer from institutional weaknesses, negatively affecting their internationalization efforts (Mesquita and Lazzarini 2008; LiPuma et al. 2013; Child et al. 2017) as well as their entrepreneurial and innovative activities (Bartholomew 1997; Busenitz et al. 2000; Bruton et al. 2005; Kiss and Danis 2008). Hence, we hypothesize that:

Hypothesis 1 The development of home country institutions is positively related to the speed of SMEs' internationalization.

\section{Firm-specific resources: previous business/international experience of the decision-maker/entrepreneur}

Internationalization requires the development of firm-specific resources and capabilities such as networking capabilities for knowledge acquisition or marketing capacities for 
access to markets (Rialp et al. 2005; Onkelinx et al. 2016). It has been suggested that the Uppsala model provides an explanation of how internationalization and learning are related. According to Johanson and Vahlne (1977), learning occurred from the firms' own experience, and may assist firms in obtaining foreign market knowledge and thus reduce the uncertainty associated with internationalization. However, the literature on firms that internationalize rapidly (i.e., INVs and born-global firms) suffers from the absence of a dominant theory that can explain the relationship between internationalization and learning (Pellegrino and McNaughton 2017). Although the literature on firms that internationalize rapidly has challenged the traditional models (i.e., Uppsala model), this stream of literature has also emphasized the role of experience in enabling firms to internationalize faster. According to this literature (e.g., Schwens and Kabst 2009; Bruneel et al. 2010), experience is gained through learning, for example, founders' previous knowledge, skills, and experience. Michailova and Wilson (2008) suggested that when international market knowledge is obtained through the manager's own experience, managers may obtain a deeper understanding than from obtaining knowledge through other methods. Therefore, experiential learning is more important for INVs and born-global firms especially when entering several international markets at the initial phase (Bruneel et al. 2010). It is believed that firms that internationalize rapidly rely heavily on congenital learning (Laperrière and Spence 2015). The firm's ability to acquire new information depends on the previous knowledge and experience of the team or on the firm's absorptive capacity. The exploitation of opportunities, and especially international opportunities, depend on the value of new information. Hence, owner-managers with previous experience/international experience may have the ability to exploit new opportunity faster than those who rely on other methods (Lecler and Kinghorn 2014). Simply, experience "may help to connect the dots" (Baron and Ensley 2006).

Moreover, previous studies based on the RBV highlighted the role of top manager's international experience as a source of firm-specific resources and tacit knowledge that has an effect on firms' internationalization (Musteen et al. 2014). It has been indicated that firm-level experience is considered an important factor for learning about internationalization. Internationalization process theory suggests that the lack of foreign market and international knowledge is an obstacle for firms during their internationalization process. Hence, firms without prior international experience may choose to enter foreign markets that require fewer resource commitments and are closer to their home markets. In contrast, firms with international and experiential knowledge can enjoy reduced risks associated with internationalization and thus expand their target markets to those distant from their home markets (Oehme and Bort 2015).

Previous research emphasizes the importance of intangible and tangible resources for rapid international expansion (Chang and Rhee 2011). With regard to intangible resources, knowledge and particularly international experience gained by the management of the firm before foundation are significant predictors of internationalization speed (Johanson and Vahlne 1977; Reuber and Fischer 1997; Dietz and Bozeman 2005; McDougall et al. 2003; Michailova and Wilson 2008; Zucchella et al. 2007; Boehe 2009; Evangelista and Mac 2016). This is because knowledge resources are especially important to mitigate the risk of international expansion. The more knowledge resources are already available at the time of foundation, the faster the management team can take internationalization decisions. According to Langseth et al. (2016), entrepreneurial knowledge can contribute to owner-managers' ability to exploit 
international opportunities. However, the empirical results are mixed. Sapienza et al. (2006), for example, find no association between international learning and the degree of internationalization, whereas Casillas et al. (2010) find that previous international knowledge and experience affect the pace of internationalization.

In this paper, we argue that prior international experience is relevant because it assists managers in identifying potential opportunities, markets, and international partners quickly, accessing foreign market knowledge and information, reducing information asymmetries and transaction costs (e.g., managing and monitoring personnel) and using their existing social networks spread across borders to assist with the internationalization process and minimize risks (Madsen and Servais 1997; Oviatt and McDougall 2005; Freeman et al. 2006; Loane and Bell 2006; Danis et al. 2009; Fernhaber et al. 2009). It is further argued that experiential knowledge is an essential factor in SMEs' capability to engage in foreign market activities (Evangelista and Mac 2016). For example, it has been suggested that in small firms, the decision-maker plays an important role in driving internationalization (Dimitratos et al. 2011). Also, experiential knowledge, gained from education or experience from living abroad (Jones and Casulli 2014), is important for the internationalization process (Johanson and Vahlne 1977; Fletcher and Prashantham 2011), which also help in reducing the uncertainty associated with internationalization (Alvarez and Barney 2005).

Previous experience of managers has also been found to be significant for SMEs in emerging markets. For example, it has been suggested that the experience of managers in a related industry may represent the firm's accumulative knowledge thus paying an important role especially for SMEs that are less likely to obtain governmental support due to their lack of political capital, compared to state-owned enterprises (Deng and Zhang 2018). Spending a long time in a related field, for example, it allows managers to gain knowledge regarding formal and informal regulations and strength their personal and business ties (Sharma et al. 2018). When facing a low quality of home-country institutions, these ties are essential for the success of the firms because they can act as a means of obtaining market knowledge and information regarding regulations and gaining resources (Zhang et al. 2016).

In addition, it has been indicated that owner-managers' international experience can be obtained in different ways (e.g., from previous involvement in the foreign market or from the owner-managers' networks, which are developed along with their experience) (Calabrò et al. 2017). According to McDougall et al. (1994), SMEs that are founded by individuals with international experience tend to internationalize their enterprises earlier than other enterprises. Moreover, owner-managers with international experience tend to have a wider network, leading to a higher degree of internationalization (Sahaym and Nam 2013). International market knowledge can enhance the absorptive capacity of firms, hence enabling owner-managers of SMEs to acquire new and additional knowledge. This knowledge can give owner-managers more confidence in dealing with the risks associated with internationalization (Liesch et al. 2011). According to Musteen et al. (2014), when firms have a greater level of foreign market knowledge, SMEs located in transition economies may have a greater ability to position their products in an effective way in the international markets.

According to the Resource-Based View (RBV), we argue that previous international experience of the owner-managers of SMEs from emerging markets form the foundation of their critical resources to consider international expansion (Gaur et al. 2018). 
Exposure to international markets may enable SMEs to adapt their strategies when they internationalize. According to Gaur et al. (2018: p. 6), export experience of SMEs in emerging markets is "likely to augment the positive effect of the home country environment." Therefore, having experience in international markets allows firms to gain knowledge regarding the type of competition they are facing and understand other challenges and risks.

In addition, the past experience of the entrepreneur can substitute a lack of organizational international experience for existing and young firms that want to go global (see Oviatt and McDougall 1994, 2005; Kor and Misangyi 2008). It has been stressed that prior knowledge (experience) allow the firm's interpretation of new information. For example, in uncertain and risky situation, such as in times of internationalization, individuals often rely on their past experience in order to deal with complexity and novelty (Grégoire et al. 2010; Figueira-De-Lemos et al. 2011). Since entrepreneurs or more generally senior managers are the key decision makers in the firm, they are more likely to rely on their own past business experience in order to approach internationalization (Reuber and Fischer 1997, 2002; Michailova and Wilson 2008; Jones and Casulli 2014). As the relationship between prior top management experience and SME internationalization is reasonably established in IE research, we explore this relationship as our baseline hypothesis for the role of resources and the speed of internationalization:

Hypothesis 2 Key decision-makers' prior business/international experience is positively related to the speed of SMEs' internationalization.

\section{The role of firm size in the experience-speed relationship}

In addition, firm size is linked to the firm-specific resources and it has been argued that the size of the firm plays an important role in determining the firm's competitiveness (Ali and Camp 1996). Moreover, it has been considered potentially important factors that determine firms' exporting behavior and success (Ganotakis and Love 2012). The size of the firm reflects both tangible and intangible resources. Larger firms, for example, have access to more resources than smaller firms, and can spread their fixed costs over a greater number of units, generating economies of scale ${ }^{2}$ in production and marketing (Oviatt and McDougall 1994). In other words, size allows an organization access to resources that micro enterprises are less likely to access, helping the firm to take risks and initiate changes towards international expansion (Dass 2000; Diamantopoulos et al. 2014). Specifically, size reflects firm resources in several ways: firms with larger numbers of employees can be assumed to have larger internal pools of skills and knowledge embedded into firm-specific routines and processes (Nelson and Winter 1982; Wagner 2001; Giovannetti et al. 2011). While managerial and entrepreneurial resources are indispensable for the (international) growth of the firm, they can only be effectively released for expansion if additional employees carry out administrative routines and operational procedures (Penrose 1959). Firms with more employees

\footnotetext{
${ }^{2}$ As one of the reviewers has pointed out, economies of scale may be important to internationalization, especially for the manufacturing industry.
} 
have also larger assets - e.g., the premises where the employees work, and the machines and tools that they use for their work; consequently, the access to financial resources improves as assets may be used as collateral for bank loans.

In spite of empirical evidence for the role of size in SME internationalization (Boehe 2013), some authors have cast doubt on the role of firm size alone as a predictor of internationalization (Bonaccorsi 1992; Calof 1994; Sousa et al. 2008). Reuber and Fischer (1997), for instance, emphasize that management's prior international experience and international partnerships are more important predictors of SME internationalization, while Calof (1994) suggest that there should exists a significant relationship between firm size and years of export/international experience.

However, while SMEs in particular seem to internationalize through partnerships and networks (Oviatt and McDougall 2005), smaller firms need to qualify first to become eligible partners. For this purpose, internationally recognized certifications, for instance, are essential in many industries. However, the certifications and product adaptations needed to meet the requirements of international partners impose high fixed costs (Mittelstaedt et al. 2003); consequently, firms need to dilute such fixed costs by increasing the scale of their operations to remain cost competitive.

As both lines of argument - that emphasizing size and firm resources and that emphasizing top management prior experience-have their recognizable theoretical merits in explaining SME internationalization, we take this conversation a step further and introduce firm size as a moderator of the relationship between key decision-makers' prior experience and internationalization speed. This is because general business and international experience, along with knowledge of international markets, may not be sufficient for rapid international expansion when the initial size of the firm does not allow economies of scale in purchasing, manufacturing, finance, or export market promotion. Conversely, increasing firm size may not be sufficient either for rapid internationalization where the decision-makers lack international management and general business experience. For these reasons, the size of the firm and prior knowledge and experience are complementary resources, the combination of which explains rapid internationalization. Accordingly, decision-makers' international and business experience likely leads to earlier internationalization if their firm also exceeds a minimum size with the associated resources. Therefore, we posit:

Hypothesis 3 The effect of prior business/international experience on internationalization speed is moderated by firm size, such that the effect becomes weaker in smaller organizations.

\section{Methodology}

\section{Latin America region}

According to the latest report of the Global Economic Prospects (GEP 2019), the activity indicators in Latin America in the first half of 2019 was slow following weak growth in 2018. This can imply that the economic conditions in the largest countries in the region are imbalanced. For example, although the financial situation has improved 
in Brazil, the activity indicators are still inactive. Chile on the other hand, is "experiencing a slowdown." However, growth in Colombia continues to improve.

From a similarities point of view, Latin American Pacific Rim economies have similar economic specialization (mining), geographical borders (Pacific), and economic growth dynamics. It also reflects the need for variability across the institutional environment. Chile started the development of free market institutions early, introducing radical reforms after 1973 and strengthening its free market institutions in the aftermath of the 1982/1983 crisis. Chile enjoys the highest degree of EF in Latin America (Fraser Institute 2014). Looking at EF indicators according to the Fraser Institute, the Chilean score for overall EF in 2012 was 7.84, tied with Finland in tenth place in the world ranking (the USA and the UK appear in twelfth place with an overall score of 7.81). It is worth noting that in 1970 Chile was at the bottom of the ranking with an overall score of 3.6 (at that time, the USA was in sixth place with an overall score of 7.8).

In addition, Peru has also strongly liberalized its economy between 1970 and 2012, moving from an overall EF score of 4.7 to 7.6. This result is, in part, due to the fast economic growth facilitated through reforms, openness to international trade, and mining industries. More than 15 Free Trade Agreements signed in the last 10 years have provided a stimulus for domestic reforms and the building of stronger institutions (Office of the United States Trade Representative 2015). Even though Colombia lags behind Chile and Peru in the EF scores, the country has made a remarkable effort to build its institutions. In particular, in the last 5 years, institutional reform has gained momentum, benefitting from the commodities booming and the diminishing threat of security risks from terrorism (Heritage Foundation 2015).

\section{Data collection}

To collect our data, we follow previous literature and define SMEs as those employing fewer than 250 employees (e.g., Dhanaraj and Beamish 2003; Wilkinson and Brouthers 2006; European Commission 2016; Oura et al. 2016). We identified our potential sample in collaboration with several institutions such as Adolfo Ibáñez University, the Emprende Foundation, and Start-Up Chile, and an online survey was designed to avoid interviewer bias (Evans and Mathur 2005). Next, we applied a multi-step protocol to validate the survey, including an initial pilot with six people: four Latin American international entrepreneurs and two Latin American industry experts. After their feedback, we improved and simplified the survey questionnaire to increase its validity. We subsequently submitted the questionnaire to the SME managers (C-level and founders), whom we asked about the firm-level characteristics at the time of their firm's foundation and at the time it started to internationalize.

The respondents were contacted by e-mail with a link to the online survey once a week for 3 weeks. Due to budget constraints, we were not in a position to contact respondents over the phone or by conventional mail. We obtained 81 valid responses. After cleaning the data, we were left with 73 responses $(60.3 \%$ from Chile; $13.7 \%$ from Colombia; $26.03 \%$ from Peru). While our overall sample is small, it is in line with prior studies using surveys in emerging economies (Harzing et al. 2013). 


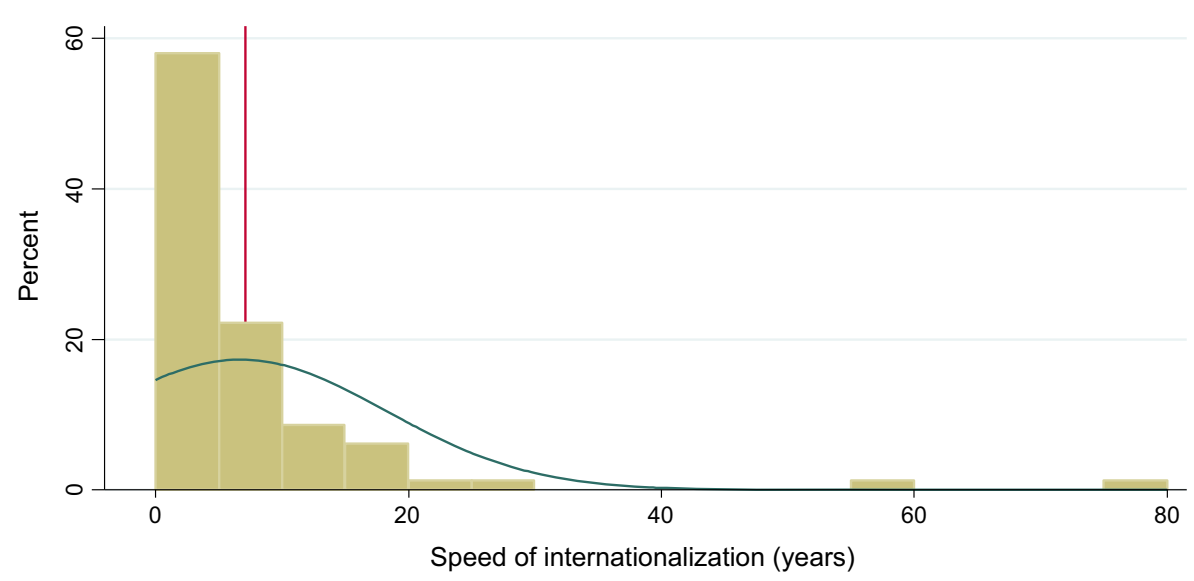

Fig. 1 The speed of SME internationalization in Latin America (Chile, Colombia, and Peru). Note: The red line indicates the mean value

\section{Measurements}

\section{Dependent variable}

The decision-makers responsible for firms' internationalization were asked to detail their business activities abroad at the time the firm began to internationalize. We developed indirect measures from their answers. The speed of internationalization is defined as the length of time elapsed $(h-n)$ between the firm's $(i)$ foundation $\left(l_{i, n}\right)$ and the year in which the firm starts to internationalize $\left(g_{i, h}\right)$ (Reuber and Fischer 1997; Zahra and George 2002; Zahra et al. 2003). Therefore, the dependent variable is the time until the beginning of the internationalization process. (Figure 1 plots the histogram of the speed of SME internationalization; the red line indicates the mean value.) Hence, this can be simply written as follows:

$$
s_{i}=g_{i, h}-l_{i, n}, \text { where } h \geq n, n=1, \ldots, N \text { and } h \in n \text {. }
$$

The data show that nearly $21 \%$ of the SMEs went global at the time of inception. About half of them became international by the third year of their lives, but after this the internationalization process slowed down. The mean speed of SME internationalization was about 7 years. ${ }^{3}$ Figure 1 shows that the data are strongly skewed to the right.

\section{Key independent variables}

Previous business and international experience of the decision-maker Our choice of indicators builds on prior research (e.g., Reuber and Fischer 1997) at the time of the firm's foundation, but we combine two indicators to better capture the overall key decision-makers' prior experience: (i) the key decision-makers' business experience, and (ii) the key decision-makers' international experience. The responses varied from (0) "none" to (5) "many years" (mean=2.73, Cronbach's alpha=0.77). At the time of the foundation,

\footnotetext{
${ }^{3}$ We find no difference in the speed of internationalization between Peru (mean=4.7 years) and Chile (mean=6.4 years). The speed of SME internationalization is found to be significantly slower in Colombia (mean=14 years) compared to Peru or Chile $(p<0.1)$.
} 
when decision-makers and founders formed a small group to run the nascent business, we can reasonably assume that the key decision-makers of the firm accurately reflect the overall experience at the firm level.

Home country institutions To measure institutionalization levels in Latin American countries, we use the EF indices developed by the Fraser Institute, Canada. Briefly, EF was first realized in 1996 with data capturing institutional characteristics of countries from 1975 to1995 and has been updated annually since (Hall and Lawson 2014). Today, it covers more than 153 countries from 1970 to 2012 . We also have focused on the EF index because it has been extensively used in the economic literature to explain cross-country differences in institutional development and liberalization (De Haan et al. 2006; Bénassy-Quéré et al. 2007; Bjørnskov et al. 2010; Gwartney et al. 2012). In particular, the literature on new institutional economics (NIE) suggests that the EF construct is the most comprehensive measure of institutional development for entrepreneurship (Gwartney et al. 2012).

The EF indices are based upon four key concepts: personal choice, voluntary transaction, free competition, and personal and property protection, which are the baseline for the empirical research. The EF indices are based on a combination of objective measures along with survey-based measures of, for example, property rights and regulations (Hall and Lawson 2014) and data collected from sources such as the World Economic Forum Global Competitiveness Report, the PRS Group International Country Risk Guide, and IMF International Financial Statistics, among others (Bénassy-Quéré et al. 2007).

Historical data are available for all the countries in the sample, and validated constructs that consider five dimensions of formal institutions for business are captured (Easton and Walker 1992). Each of the five dimensions of institutional development is measured on a scale from 0 ("no economic freedom") to 10 ("full economic freedom") at the time of internationalization: (a) government size (mean=7.26); (b) legal system and property rights (mean=5.75); (c) access to sound money (mean=8.32); (d) freedom to trade internationally (mean=7.88); and (e) regulations (mean=7.05), which include credit market regulations, labor market regulations, and business regulations. The mean of the overall index is found to be 7.25; Chile (mean=7.61) is found to exhibit higher EF than Colombia (mean=6.29) and Peru (mean=6.92), the latter countries reporting similar levels of EF. ${ }^{4}$

Firm size The size of the firm, measured as the number of employees at the initial internationalization stage, represents the degree to which a firm may be able to economize on scale, a key determinant of potential cost-based competitive advantage. ${ }^{5}$

\footnotetext{
${ }^{4}$ We find a statistically significant difference in the means when Chile is compared to both Colombia and Peru $(p<0.01)$.

${ }^{5}$ Firm size may vary between the time of the firm's foundation and its time of international entry. Using the firm's modal size can ensures that each firm corresponds to one size category (for discussion, see Ferreira and Saridakis 2017). Due to data limitations, however, we cannot observe changes occurred in the firm size between the two periods. However, most of the firms (63\% of the sample) have employee size of less than 10 employees at the time of international entry (mean internationalization speed is found to be equal to 3 years). For these firms, the firm size category (i.e., micro firms) at the time of international entry is equal to the firm size category at the founding year. For the larger size firms (with estimated mean internationalization speed of 13 years), we assume that modal size category is likely to correspond to the firm size reported at the time of the international entry than the time of firm's foundation. This is because growth rates tend to decline as the firm becomes older (see Storey 1994) suggesting that within the elapsed period the modal firm size category is likely to be equal the firm size observed at the time of the international entry. However, future longitudinal research should address this issue.
} 
According to Ayyagari et al. (2003), the upper limit designating an SME in Chile, Columbia, and Peru is 200 employees, which is lower than that used in the EU (250 employees) and USA (500 employees). The survey, however, asks the participants to categorize their firm into the following sized bands: 1 if the firm has fewer than ten employees $(63.01 \%), 2$ if the firm has more than ten and fewer than 49 employees $(21.92 \%), 3$ if the firm has between 50 and 99 employees $(8.22 \%)$, and 4 if the firm has more than a hundred and fewer than 250 employees $(6.85 \%)$. To study and contrast the effects of different sized firms on the speed of internationalization, we use the full firm size information provided in our specification.

Industry, location, and other control variables We further argue that differences across industries (e.g., competition level, research intensity, human/financial capital requirements) and industry-specific cycles may influence the motivation to internationalize and the speed of internationalization. Hence, industry dummies are included in the model to capture potential differences in the degree and the speed of internationalization that may arise from industry shocks and industry-specific shifts and barriers (e.g., industries with high capital needs). The extant literature suggests that industry plays a significant role in the internationalization process (Bell 1995; Andersson 2004). As discussed in Zahra and Garvis (2000), firms in different sectors face different challenges and thus require different strategic behavior regarding internationalization. Teixeria and Coimbra (2014) suggest that only a small number of published papers examine the internationalization speed across different sectors. Zhou and Wu (2014), for example, find no industry effect on firms' internationalization speed for firms located in China. In contrast, Madsen (2013) provides evidence that sector is related to early internationalization.

We also control for country (location of the firm) and destination of internationalization (foreign market in which the firm operates) to capture differences (e.g., cultural, technological and other differences) in the home country as well as unobserved heterogeneity across foreign countries (e.g., SMEs prefer foreign markets closer to their homes) ${ }^{6}$.

Finally, we include a variable to capture the key decision-makers' level of education at the time of the firm's foundation: $6.85 \%$ have received some form of school qualification, $54.79 \%$ have an undergraduate degree, and $38.36 \%$ have a postgraduate qualification. We argue that the educational level helps them to interpret the global market. Additionally, the educational level reflects the likelihood that managers have gained foreign language skills - i.e., English as a foreign language, which strongly underpins international experience.

\section{The model}

As discussed earlier, we aim to extend the institutional theory and the RBV in international business context, for SMEs from emerging economies by proposing a theoretical model that allows to study the effect of home country institutions (home

\footnotetext{
${ }^{6}$ Due to data limitations, the destination of internationalization construct cannot be further disaggregated. We leave this for future research.
} 
country-specific resources), and previous business/international experience and firm size (firm-specific resources) on the speed of internationalization, controlling for industry and other characteristics. More specifically, the model is first testing whether home country-specific institutions, in terms of the economic of freedom index capturing government size, legal system and property rights, access to sound money, freedom to trade internationally, and regulations, have a direct effect on the internationalization speed of SMEs in Latin America. Second, the model is examining if firm-specific resources, in terms of firms' human capital (i.e., previous business/international experience of the owner-manager of the firm), has a direct impact on SME internationalization speed. Finally, the model tests whether firm size moderates firm-specific resources and the internationalization speed relationship. The conceptual framework is presented in Fig. 2. Summary statistics of the variables included in the model and correlations associated with them are presented in Table 1.

This study models the time to internationalization (for which time is treated as a discrete variable) using a Poisson model. A random variable is said to have a Poisson distribution with parameter $\lambda$ if it takes integer values $(0,1,2, \ldots)$ with probability:

$$
P\left(s_{i}\right)=\frac{\lambda_{i}^{s_{i}} \exp \left(-\lambda_{i}\right)}{n_{i} !}
$$

The expected speed of internationalization is assumed to be a function of a number of covariates such that:

$$
\lambda_{i}=\exp \left(\beta X_{i}\right)
$$

where $\beta$ is the coefficient vector to be estimated and $X_{i}$ is a vector of explanatory variables including previous experience, home market institutions, firm size, and industry and location dummies. The parameters can be estimated by the maximum likelihood (ML) method.

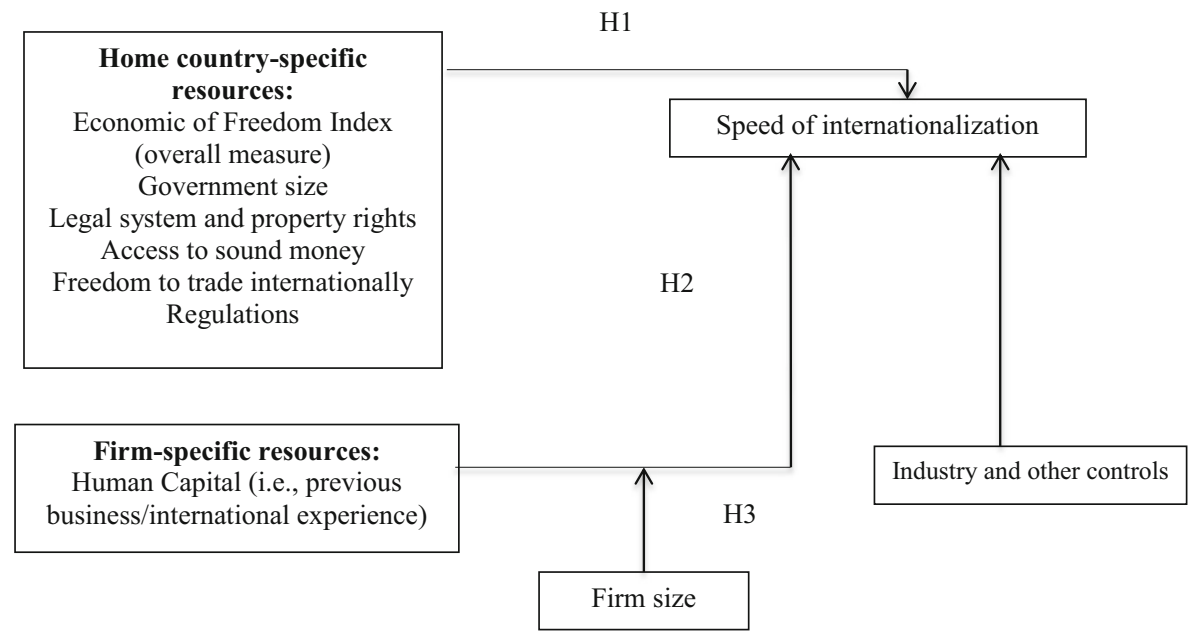

Fig. 2 Conceptual framework 
A negative binomial (NB) regression model is also estimated to overcome a potential over-dispersion problem (e.g., in the case of unobserved heterogeneity) by allowing the conditional variance to differ from the conditional mean. Hence, an error term is added to $\lambda_{i}$ such that:

$$
\lambda_{i}=\exp \left(\beta X_{i}+\varepsilon_{i}\right)
$$

\section{Empirical results}

The estimation results of the Poisson and NB models are presented in Table 2. The dependent variable indicates the time elapsed (in years) until the firm internationalized. A likelihood ratio (LR) test comparing the NB model to the Poisson model is estimated. The dispersion parameter $(\alpha)$ is significantly different from 0 , confirming the appropriateness of the negative binomial models, 2 and 4, relative to the Poisson model, 1 and 3. However, we also report the Poisson regression models as a reference.

The coefficient of the total EF measure is found to be statistically insignificant in models 1 and 2, suggesting that the development of market institutions does not matter for SMEs' internationalization speed. However, when the measure is disaggregatedmodels 3 and 4 -the results are striking. We find that improvements in the areas of both government size and regulation reduce the time between inception and internationalization activity - in other words, they both increase the speed of internationalization. The latter variable has the larger coefficient, twice the size of the coefficient of the former variable. In contrast, however, the freedom to trade internationally and legal systems and property rights variables display statistically insignificant coefficients in model $4 .^{7}$ A possible explanation for the non-significant effect resides in the fact that institutions affect the development and accumulation of firm resources as well as competitive intensity (North 1990). Thus, the effect of these areas may already be contained in resource drivers. Interestingly, we further find that access to sound money (capturing macroeconomic and price stability) decelerates internationalization speed. Perhaps economic stability within the home country reduces the need to seek stable markets abroad and allows firms time to identify international markets to enter more strategically.

Turning to the role of management's prior (business and international) experience and their educational level in speed of internationalization, we find a strong association with the former but no association with the latter; we suggest that formal educational

\footnotetext{
${ }^{7}$ We have also experimented by estimating the model allowing for interactions between the EF and prior experience/international experience variables. However, the interaction coefficients are found to be statistically insignificant, whereas the coefficients of the main effects of access to sound money and regulation are inflated. In contrast, the coefficient of government size becomes statistically insignificant. When the interactions are included one at the time, only the interaction coefficient between legal system and property rights is found to be negative and statistically significant (coeff. $=-0.237$, Std. Error $=0.101$ ). This is an interesting area that deserves future research attention when bigger samples are available to allow for more detailed examination of the data.
} 
Table 1 Summary statistics of the variables

\begin{tabular}{|c|c|c|c|}
\hline Variables & $\%$ & Mean & Std. dev. \\
\hline Speed of internationalization (in years) & & 7.055 & 11.966 \\
\hline \multicolumn{4}{|l|}{ Home market institutions } \\
\hline Economic freedom (overall mean) & & 7.254 & 0.993 \\
\hline Government size & & 7.264 & 0.807 \\
\hline Legal system and property rights & & 5.750 & 1.409 \\
\hline Access to sound money & & 8.323 & 1.962 \\
\hline Freedom to trade internationally & & 7.882 & 1.227 \\
\hline Regulations & & 7.051 & 0.454 \\
\hline \multicolumn{4}{|l|}{ Human capital } \\
\hline Prior business/international experience (unstandardized item)* & & 2.733 & 1.429 \\
\hline Education (base category: postgraduate degree) & 38.356 & & \\
\hline School level qualification & 6.849 & & \\
\hline Undergraduate degree & 54.795 & & \\
\hline \multicolumn{4}{|l|}{ Firm characteristics } \\
\hline Firm size (base category: 100-249 employees) & 6.849 & & \\
\hline$<10$ employees & 63.014 & & \\
\hline 10-49 employees & 21.918 & & \\
\hline 50-99 employees & 8.219 & & \\
\hline Industry (base category: professional services) & 56.164 & & \\
\hline Primary & 13.699 & & \\
\hline Manufacturing & 23.288 & & \\
\hline Retail & 6.849 & & \\
\hline Location of the firm (base category: Peru) & 26.027 & & \\
\hline Chile & 60.274 & & \\
\hline Colombia & 13.699 & & \\
\hline Destination of internationalization (base category: Latin America) & 46.575 & & \\
\hline USA, Canada, and Europe & 39.726 & & \\
\hline Rest of the world & 13.699 & & \\
\hline
\end{tabular}

*For the empirical model, the scale is constructed by using standardized values of the individual items.

qualifications are an imperfect measure of entrepreneurial talent and ability, and prior experience is a better predictor to explain dynamic entrepreneurial decisions. ${ }^{8}$

Additionally, we find that firm size affects the speed of internationalization, with smaller firms climbing the internationalization ladder faster. ${ }^{9}$ The coefficients of industry dummies are generally not statistically significant, the sole exception being the coefficient of manufacturing. In other words, taking professional services as the reference category, the speed of internationalization of firms in manufacturing is found to be lower than the reference category. In regard to the country dummies, we find some evidence that Colombian firms, on average, take more time to internationalize

\footnotetext{
${ }^{8}$ We have also estimated the model by including the two experience variables separately. In this case, only the coefficient of international experience is found to be statistically significant. The marginal effects are plotted in Fig. 3 in the Appendix.

${ }^{9}$ Using the midpoints of firm size and interacting this construct with the prior experience variable leads to similar conclusions.
} 


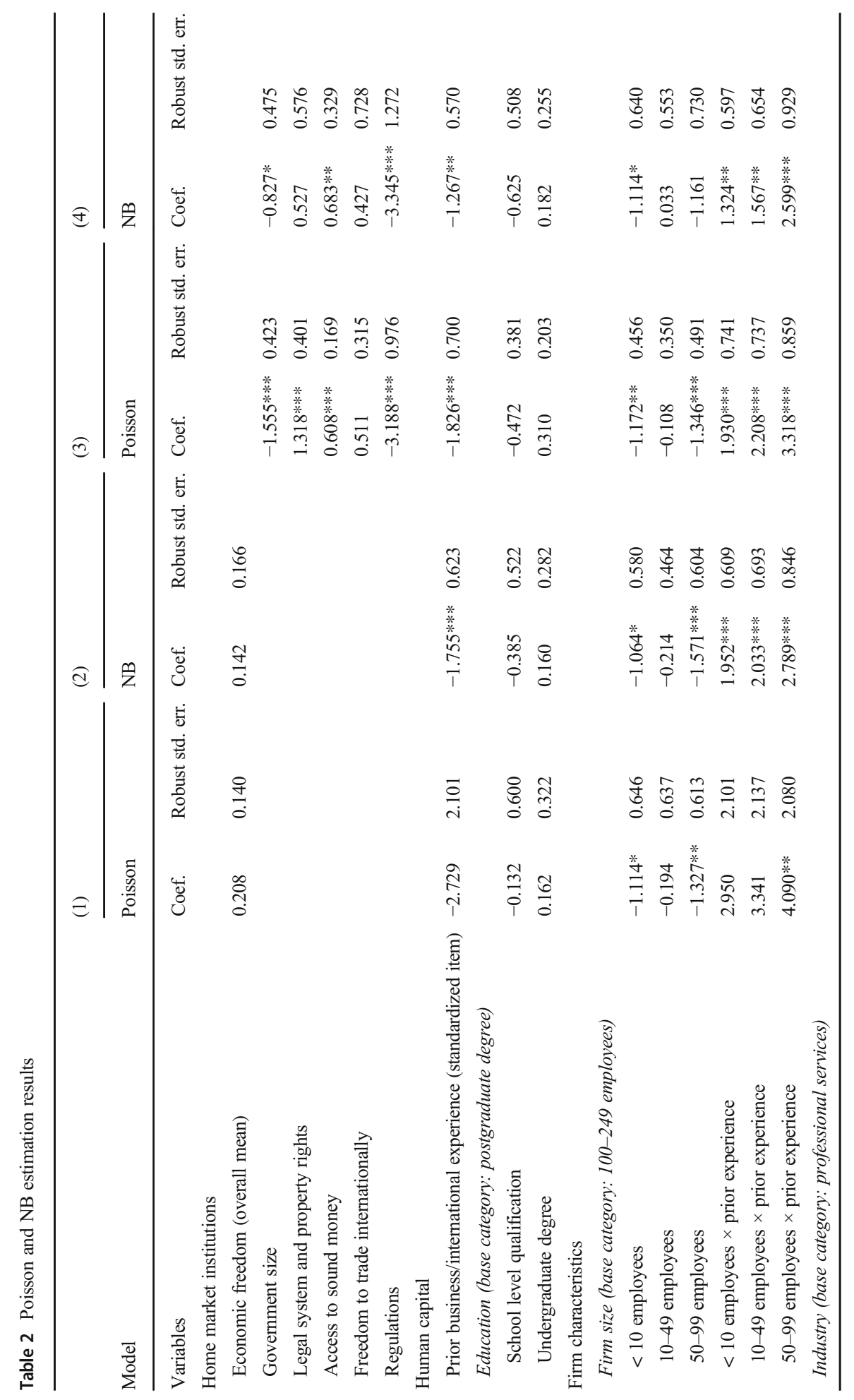




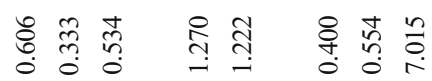

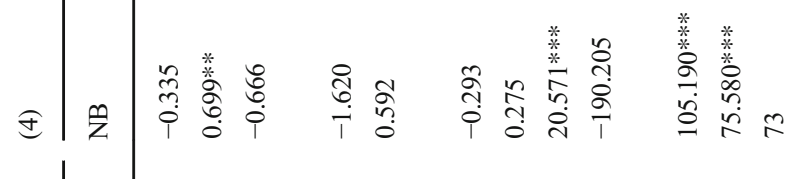

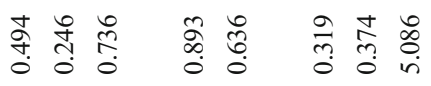

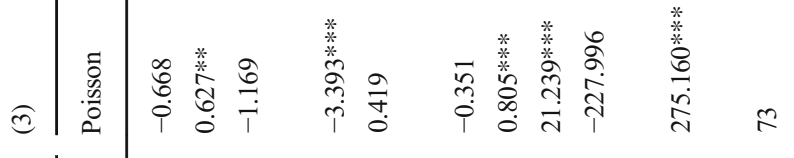

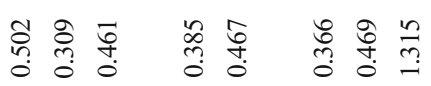

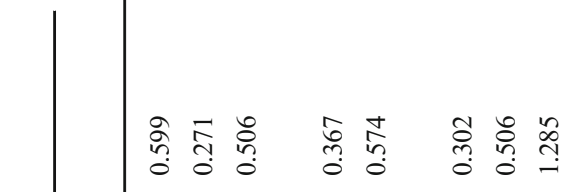

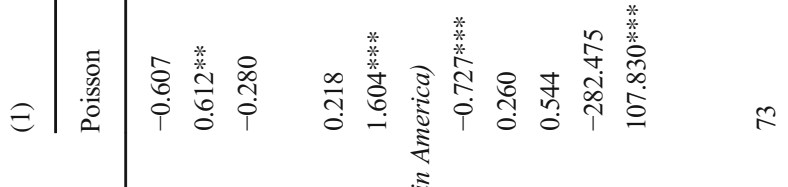


than Peruvian firms, whereas Chilean firms take less time. Finally, destination of internationalization is found to exert a weak effect on the time to internationalize.

\section{Discussion}

This paper directly responds to a call for more research on internationalization of SMEs from emerging markets (e.g., Coviello and Jones 2004; Coviello 2006; Autio et al. 2011; Bianchi et al. 2017). Drawing on the institutional theory (home country-specific resources) and the resource-based view (firm-specific resources), this paper contributes to the understanding of how home country institutions and developing entrepreneurial capabilities in SMEs, such as previous business/international experience, contribute to SME internationalization speed in Latin America. It has been suggested that in this region, firms' specific resources are originated from the managerial assets, while country-specific resources are originated from its institutional environment. Therefore, we use these theories jointly in order to understand how the level of economic of freedom, and owner-managers' previous business/international experience and the size of the firm, can affect the internationalization speed of SMEs in emerging markets.

This paper has empirically examined the effect of economic freedom, business/ international experience, and firm size on the speed of internationalization for SMEs in three Latin American countries - Chile, Colombia, and Peru. Firstly, the results suggest that only some areas of EF might speed up internationalization, providing partial support for Hypothesis 1. In particular, the results show that improvements in government size and regulations increase SMEs' internationalization speed. This in the line with existing research that has advocated the importance of home country institutions for internationalization behavior (Sol Patricio and Kogan 2007; Gao et al. 2010). For example, Gao et al. (2010) finds that home country institutions in the form of free market mechanism development are strongly associated with the propensity to export and exporting intensity. Hence, their conclusion is that improvements in institutional environment provide supporting environment for exporting SMEs. In addition, it is widely assumed that the level of market freedom in the home country of firms can affect the internationalization decision and the timing to internationalize (Dickson et al. 2013). The premise of such an assumption is that since SMEs have limited resources, a lower level of economic burden placed by the government will allow the firm to exploit internationalization opportunities. However, existing research has also drawn attention to the fact that home country institutions may affect smaller firms differently from how they affect large firms; likewise, home country institutional variations seem to make a notable difference, particularly to small and large firms (Shinkle and Kriauciunas 2010; Deng and Zhang 2018). Larger firms lie beyond the scope of this study, but future international entrepreneurship and strategy research should examine the role of institutions in larger sized firm than those studied here.

Secondly, we find that owner-managers' business/international experience reduces the time between start-up and the occurrence of internationalization. Our results are consistent with previous literature (e.g., Javalgi and Todd 2011; Cui et al. 2013), indicating that the experience and knowledge of the owner-manager affect the internationalization speed (e.g., Casillas et al. 2010). Therefore, our paper provides empirical evidence for SMEs in Latin America which support previous research that stresses the importance of business/international experience in internationalization. Moreover, it 
has been found in previous research that internationally oriented owner-managers of small firms tend to have a positive attitude towards internationalization and, more specifically, exporting, due to the fact that they have the appropriate experience in dealing with international markets (Nummela et al. 2004). Therefore, it can be argued that internationally experienced entrepreneurs have been socialized abroad and have likely adopted an entrepreneurial mind-set molded by other countries' institutional frameworks. Moreover, when a firm follows an international growth strategy at high speed, the firm will more likely gain advantages from the foreign market (Grant 2010). Therefore, the firm will gain access to resources and greater opportunities over its competitors. By following this behavior, the firm will gain positive economic profits and the economies of scale will be reached more quickly, therefore enhancing firm performance.

Moreover, international experience may allow firms to develop a set of skills and knowledge useful of internationalization. More specifically, international experience may improve the firms' abilities to overcome the liability of foreignness and reduce the cost and time associated with internationalization (Barkema et al. 1996). It has been suggested that prior international experience derived from operating in other countries will allow SMEs to adapt to the host country specification, such as customers' demands and legal rules. Hence, the experiential learning associated with international experience may allow for rapid internationalization. Our results are in line with RBV-based studies highlighting the importance of top managers' international experience as a source of firm-specific and tacit knowledge which affects firms' internationalization (Barney et al. 2001). Research on entrepreneurship in general has highlighted that entrepreneurs learn from their experience and are more likely to be able to exploit new opportunities in general and internationalization opportunities in particular (Musteen et al. 2010). This is also in the line with the international entrepreneurial capabilities (IECs), which implies that firm's previous international experience allows the firm to exploit resources internationally (Teece 2016).

However, when prior business/international experience is interacted with firm size, we observe that prior business/international experience increases the time to internationalize for smaller firms compared to larger sized SMEs. In other words, prior experience pays off in larger sized SMEs more than in smaller ones. These results are in line with previous literature indicating that "larger firms are more likely to have teams with international selling experience" (Reuber and Fischer 1997: p. 818). Hence, Hypothesis 2 is only partly supported, while we find empirical support for Hypothesis 3.

In conclusion, our paper makes the following contributions to the IE, IB, and strategy research. Firstly, we directly respond to the call regarding research on SMEs from Latin American region, a relatively under-researched region with most of the existing research focusing on Mexico and Brazil (e.g., Coviello and Jones 2004; Coviello 2006; Autio et al. 2011; Cardoza et al. 2016; Bianchi et al. 2017). By doing so, we are able to contribute to the literature by providing more insight regarding emerging markets' SME internationalization, considering the geographical context of emerging economies in which these firms operate. The results of this paper will enable policy-makers to create appropriate policies to stimulate economic growth and gain economic development in these emerging markets. Secondly, we contribute to the existing literature by filling the gap regarding the role of institutional environment in emerging economies on the speed of internationalization, a gap that exists in the current literature (e.g., Laufs and Schwens 2014; Hitt et al. 2016; Knight and Liesch 2016) 
since findings from developed economies do not apply to emerging markets. Finally, we have empirically examined the size of the firm as a moderator for the relationship between business/international experience and internationalization speed. Our results have shown that experience pays off only for larger sized SMEs. By doing so, we contribute to the current literature by shedding light on the effect of firm size as a moderator in the business/international experience-internationalization nexus.

While previous studies on developed countries focused on the exploitation of how firm-specific resources assist firms to internationalize (Buckley and Casson 1976), emerging market SMEs differ significantly from their counterparts in the West and although transition and emerging economies are generally assumed to share some institutional similarities (e.g., related to Soviet style government), there exists significant differences in these countries (Chavance 2008). The unique characteristics of enterprises from emerging economies prompt the need for new understanding of the sources of competitive advantages that enable firms to internationalize. By overcoming trade barriers, in which technological progress and communication infrastructure have contributed to, emerging economies have been increasingly attracting a significant share of FDI. This has contributed positively to economic growth and innovation (Cardona et al. 2013; Abubakar et al. 2019).

In this paper, it has been argued along with existing research that geographical context plays a significant role in studying firms' internationalization (Deng et al. 2020). Specifically, although previous literature has acknowledged that home-country institutions assist firms' international activates (Wang et al. 2012), knowledge on how and under what institutional circumstances such effect occur is limited (Hong et al. 2015). Therefore, our study contributes to previous literature by extending the institutional theory and the RBV, in international business context for SMEs in Latin American region, and stimulates further theoretical and empirical research in this area of research and economies.

\section{Conclusion}

During the past few years, "emerging market economies, including several countries in Latin America, are regarded as new engines of economic growth" (Martin and Javalgi 2016: p. 2040). Also, firms in Latin America have proven that they are equal to their counterparts in other regions in terms of business innovation and entrepreneurship, playing a critical role in investment and trade internationally.

Despite the growing attention from academics to firms from Latin America, the majority of previous studies have concentrated on multinational corporations (e.g., Luo and Tung 2007; Ciravegna et al. 2014), while SMEs from this region have received less research attention. This limited stream of existing research has focused on very specific aspects such as the growth, survival, and development of small firms in Latin American's region or the barriers that affect entrepreneurial activities (e.g., Swaminathan 1996; West et al. 2008). Hence, there is an incomplete knowledge regarding SMEs from this region (Cardoza et al. 2016) that can lead to weaker regulations, under-developed public policies, and low level of firms' competences to overcome challenges for expansions (West et al. 2008; Cardoza et al. 2016). To this end, more research regarding SMEs in this region is needed in order to fill in the gaps in previous literature. 
In addition, there has been growing attention to the internationalization of SMEs. More specifically, an increasing number of SMEs from emerging economies are expanding their businesses abroad (Aulakh et al. 2000) generating economic growth and creating jobs in emerging markets (Bianchi et al. 2017). Hence, academics and government increasingly recognize the importance of gaining better understanding of the internationalization process for SMEs from emerging markets. However, previous studies have mainly focused on large firm from developed countries (Olejnik and Swoboda 2012) and less attention has been paid to SMEs from emerging markets (Bianchi and Wickramasekera 2016) and in particular to SMEs in Latin American region (Bianchi et al. 2017). Moreover, despite the growing importance of emerging economies and the important role played by the entrepreneur in advancing the economy and its growth, our undersetting of IE in emerging economies is still limited (Kiss et al. 2012). For example, it has been suggested that the existing strategy of "market liberalization" in Latin America depends to a great extent on entrepreneurship, and thus, a better understanding of the internationalization process of firms in this region is essential in order to enable their international expansion (Filatotchev et al. 2009; Felzenszetein and Fuerst 2018). However, although firms from this region are growing, they still face significant barriers. For example, it has been suggested that SMEs in Latin America still exhibit a low level of internationalization compared to their European counterparts, face significant challenges from the increased international competition (especially from Chinese firms), and are unable to benefit from global value chains (Chan et al. 2008; ECLAC 2013). ${ }^{10}$

Therefore, in this paper, we examine the role of EF, prior business/international experience, and firm size on speed of internationalization in Latin American Pacific Rim SMEs, controlling for industry and location. Given the important role played by the entrepreneur during the internationalization process, especially in the resource-constrained environments that characterize emerging economies, it is essential to understand how the unique external environment shapes firms' plans and further affects their internationalization speed. We explore this issue by drawing on the home countryspecific resources, in the form of the home country institutions, and the firm-specific resources in the form of previous business/international experience and firm size on the internationalization speed for SMEs from emerging economies. We focus on understanding how these factors affect SMEs to peruse early and accelerated process of internationalization (Oviatt and McDougall 1994; Knight and Kim 2009) instead of the traditional patterns of internationalization theories dominating IB literature. Hence, our paper contributes to the IE literature by providing important insights into IE phenomena in a much broader range of institutional contexts than have been examined to date (Kiss et al. 2012).

The study finds that some home country institutional drivers can explain internationalization speed; specifically, it is found that government size and regulation accelerate the internationalization process. However, not all areas of EF are found to be adequate for the promotion of IE. Therefore, we argue that public programs or agencies should provide entrepreneurs with the means to help them rapidly scale up their business, and this involves using existing institutions. In addition, it has been indicated by Bianchi and Wickramasekera (2016) that companies in the Latin American region require assistance to commit to internationalization. The most important

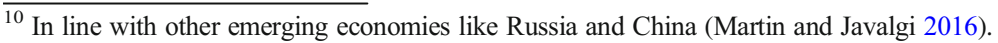


factor which appears to be helpful is to provide training for owner-managers of small firms through government agencies. Policy-makers in these regions should therefore recognize the need to establish different kinds of public agency and programs which aim to help owner-managers of small firms to expand their businesses abroad.

Moreover, although previous studies highlighted the role of international experience (Dikova et al. 2010; Clarke et al. 2013) as an important factor in relation to the effects and outcomes of internationalization, its role in determining the internationalization speed of firms remains underexplored (Mohr and Batsakis 2014). We fill in the gap in the literature. We have examined the relationship between prior business/international experience and SMEs' internationalization speed for SMEs in an emerging market. We find that prior experience can accelerate internationalization, but this pays off only for larger sized SMEs, in contrast to those that are smaller. We suggest that existing SMEs with a minimum size should be connected to internationally experienced entrepreneurs (e.g., by inviting them to become part of their boards of directors) who can assist these firms in speeding up their internationalization. For example, the Chilean export promotion agency PROCHILE launched a Programme for International Entrepreneurs in 2014. This program might serve as a reference model for similar IE support programs to be developed in other Latin American countries. This is important due to the rising relevance of international entrepreneurs in economic growth and the distinct behavior of internationalizing SMEs compared to more established large and multinational corporations. We therefore suggest that owner-managers of smaller sized firms that do not possess the required international experience to expand their business abroad participate in such programs and seek advice and assistance from internationally experienced entrepreneurs.

In spite of its important implications, this study is not without limitations. Firstly, the sample size limits the predictive power of our econometric models. Specifically, having obtained responses mainly from firms from the more liberalized economies (Chile, Colombia, and Peru), this did not allow us to compare them with international entrepreneurs from much less liberalized countries (e.g., Argentina, Bolivia, Ecuador, and Venezuela). Finer-grained differences across the more liberal countries are, of course, more difficult to detect with a small sample. Therefore, future studies can advance this stream of research by sampling a larger pool of SMEs in other, less liberalized, Latin American countries in addition to the countries we have already covered. Furthermore, due to data constraints, this study was not in a position to operationalize the home country market environment considering industry-specific characteristics. Future research might advance this stream of research by considering less aggregated industry-level data. In particular, it would be useful to understand how more specific industry characteristics, such as domestic inter-firm rivalry and domestic buyer bargaining power, among others, affect internationalization speed and international intensity. Also, market growth abroad is likely to influence a firm's international strategy and, in particular, the decision to internationalize. This is because an income increase in foreign countries can lead to an increase in demand for the products and services provided by key trading partners. Hence, foreign market growth can motivate firms to enter such growing foreign markets more rapidly and thus increase internationalization speed. Future empirical research should investigate the effect of actual measures of industry growth and size on speed of internationalization.

Finally, this study intentionally focused only on the initial internationalization phase. Future research might expand on our approach, considering additional phases of the 
internationalization process using longitudinal data - in particular, (i) internationalization preparation and (ii) internationalization evolution. Thus, IE research will gradually move towards a more comprehensive picture. Additionally, comparing firm internationalization experience between emerging and developed markets may offer further theoretical and empirical insights. Moreover, although our study has been approached quantitatively due to the nature of the data collection, we encourage further work using a qualitative approach. For example, in-depth interviews with business owners can reveal further insights into the effect that various home institutions can have on internationalization speed.

\section{Appendix}

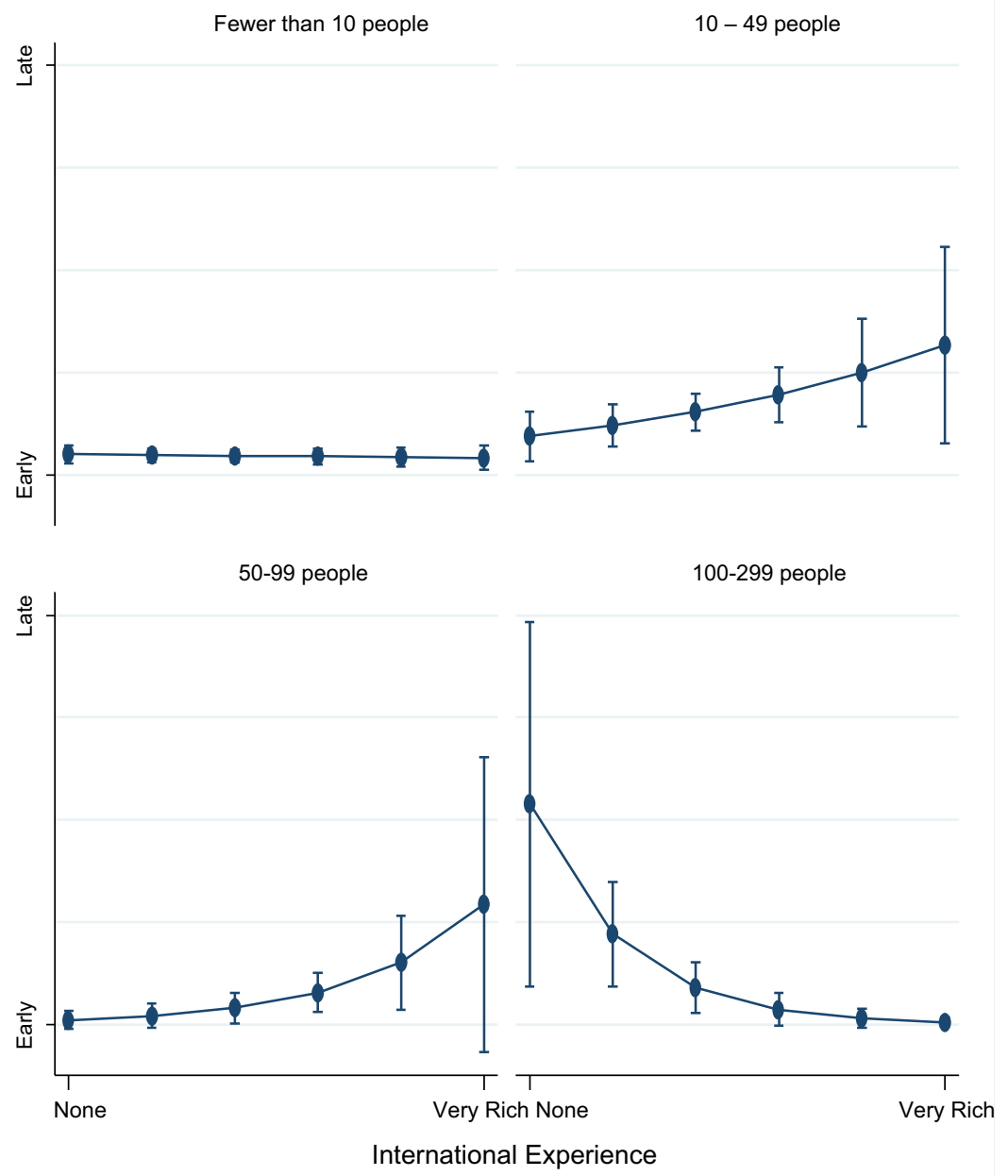

Fig. 3 Marginal effects of firm size with $95 \%$ CI 
Acknowledgements The authors would like to thank Chris Hand, Dirk Michael Boehe, and Luiz Ricardo Kabbach De Castro for comments and suggestions on an earlier version of this paper. Also, we would like to thank the referees and the editor for the valuable comments and suggestions that have improved the paper in various ways.

Open Access This article is licensed under a Creative Commons Attribution 4.0 International License, which permits use, sharing, adaptation, distribution and reproduction in any medium or format, as long as you give appropriate credit to the original author(s) and the source, provide a link to the Creative Commons licence, and indicate if changes were made. The images or other third party material in this article are included in the article's Creative Commons licence, unless indicated otherwise in a credit line to the material. If material is not included in the article's Creative Commons licence and your intended use is not permitted by statutory regulation or exceeds the permitted use, you will need to obtain permission directly from the copyright holder. To view a copy of this licence, visit http://creativecommons.org/licenses/by/4.0/.

\section{References}

Abubakar YA, Hand C, Smallbone D, Saridakis G (2019) What specific modes of internationalization influence SME innovation in Sub-Saharan least developed countries (LDCs)? Technovation 79(C):56-70

Acquaah M (2007) Managerial social capital, strategic orientation, and organizational performance in an emerging economy. Strateg Manag J 28(12):1235-1255

Ali A, Camp R (1996) Firm size and international business experience: Their impact on export behavior. Adv Competitive Rev 4(1):143-162

Alvarez SA, Barney JB (2005) How entrepreneurs organize firms under conditions of uncertainty. J Manag 31:776-793

Amit R, Schoemaker RJ (1993) Strategic assets and organizational rent. Strateg Manag J 14(1):33-46

Amoros J, Bosma N (2014) Global entrepreneurship monitor-2013 global report-fifteen years of assessing entrepreneurship across the globe, Global entrepreneurship research association. Croom-Helm, New York, pp 287-314

Andersson S (2004) Internationalization in different industrial contexts. J Bus Ventur 19(6):851-855

Andersson S, Evers N, Kuivalainen O (2014) International new ventures: Rapid internationalization across different industry contexts. Eur Bus Rev 26(5):390-405

Arregle JL, Miller TL, Hitt MA, Beamish PW (2013) Do regions matter? An integrated institutional and semiglobalization perspective on the internationalization of MNEs. Strateg Manag J 34:910-934

Arte P (2017) Role of experience and knowledge in early internationalisation of Indian new ventures: A comparative case study. Int J Entrep Behav Res 23(6):850-865

Aulakh PS, Kotabe M, Teegen H (2000) Export strategies and performance of firms from emerging economies: Evidence from Brazil, Chile, and Mexico. Acad Manag J 43(3):342-361

Autio E, Sapienza HJ, Almeida JG (2000) Effects of age at entry, knowledge intensity, and imitability on international growth. Acad Manag J 43(5):909-924

Autio E, George G, Alexy O (2011) International entrepreneurship and capability development-qualitative evidence and future research directions. Entrepreneurship Theory and Practice 35(1):11-37

Ayyagari M, Demirgüç-Kunt A, Beck T (2003) Small and medium enterprises across the globe: A new database. World Bank Policy Research Working Paper, NO:3127

Azman NA, Mohammad O, Ahmad NH (2018) Understanding the effect of home country institutional pressures towards internationalization strategies among Malaysian SMEs. J Adv Res Bus Mark Supply Chain Manag 2(1):1-8

Azzi da Silva P, da Rocha A (2001) Perception of export barriers to Mercosur by Brazilian firms. Int Mark Rev 18(6):589-611

Baker T, Gedajlovic E, Lubatkin M (2005) A framework for comparing entrepreneurship processes across nations. J Int Bus Stud 36(5):492-504

Barkema HG, Bell JHJ, Pennings JM (1996) Foreign entry, cultural barriers, and learning. Strateg Manag J 17 (2):151-166

Barney J (1991) Firm resources and sustained competitive advantage. J Manag 17(1):99-120

Barney JB (2001) Is the resource-based "view" a useful perspective for strategic management research? Yes. Acad Manag Rev 26(1):41-56 
Barney J, Wright M, Ketchen DJJ (2001) The resource-based view of the firm: Ten years after 1991. J Manag 27(6):625-641

Baron RA, Ensley MD (2006) Opportunity recognition as the detection of meaningful patterns: Evidence from comparisons of novice and experienced entrepreneurs. Manag Sci 52(9):1331-1344

Bartholomew S (1997) National systems of biotechnology innovation: Complex interdependence in the global system. J Int Bus Stud 28(2):241-266

Bathelt H, Gluckler J (2003) Toward a relational economic geography. J Econ Geogr 3(2):117-144

Baumol W, Litan RE, Schramm CJ (2009) Good capitalism, bad capitalism, and the economics of growth and prosperity. Yale University Press, New Haven

Bell J (1995) The internationalisation of small computer firms - A further challenge to "stage" theories. Eur J Mark 29(8):60-75

Bénassy-Quéré A, Coupet M, Mayer T (2007) Institutional determinants of foreign direct investment. World Econ 30:764-782

Bianchi C, Wickramasekera R (2016) Antecedents of SME export intensity in a Latin American market. J Bus Res 69:4368-4376

Bianchi C, Glavas C, Mathews S (2017) SME international performance in Latin America: the role of entrepreneurial and technological capabilities. J Small Bus Enterp Dev 24(1):176-195

Bianchi C, Carneiro J, Wickramasekera R (2018) International commitment of emerging market firms: A comparative study of Chile and Brazil. J Small Bus Enterp Dev 25(2):201-221

Bjørnskov C, Dreher A, Fischer J (2010) Formal institutions and subjective well-being: Revisiting the crosscountry evidence. Eur J Polit Econ 26(4):419-430

Boehe DM (2009) Brazilian software SME's export propensity: Bridging "born global" and stage approaches. Lat Am Bus Rev 10(2-3):187-216

Boehe DM (2013) Collaborate at home to win abroad: How does access to local network resources influence export behavior? J Small Bus Manag 51(2):167-182

Boehe DM, Qian G, Peng MW (2016) Export intensity, scope, and destinations: Evidence from Brazil. Ind Mark Manag 57:127-138

Bonaccorsi A (1992) On the relationship between firm size and export intensity. J Int Bus Stud 23(4):605-635

Brache J, Flezensztein C (2019) Exporting firm's engagement with trade associations: Insights from Chile. Int Bus Rev 28:25-35

Brenes ER, Haar J (2012) The future of entrepreneurship in Latin America. Palgrave McMillan, New York

Brenes ER, Montoya D, Ciravegna L (2014) Differentiation strategies in emerging markets: The case of Latin American agribusinesses. J Bus Res 67(5):847-855

Brenes ER, Ciravegna L, Pichardo C (2018) Managing institutional voids: A configurational approach to Under-standing high Performance antecedents. J Bus Res 105:345-358

Bruneel J, Yli-Renko H, Clarysse B (2010) Learning from experience and learning from others: How congenital and interorganizational learning substitute for experiential learning in young firm internationalization. Strateg Entrep J 4:164-182

Bruton HJ (1998) A reconsideration of import substitution. J Econ Lit 36(2):903-936

Bruton GD, Fried VH, Manigart S (2005) Institutional influences on the worldwide expansion of venture capital. Enterp Theory Pract 29(6):737-760

Bruton GD, Ahlstrom D, Li H-L (2010) Institutional theory and entrepreneurship: Where are we now and where do we need to move in the future? Entrep Theory Pract 34(3):421-440

Buckley PJ, Casson MC (1976) The future of the multinational enterprise. Homes \& Meier, London

Buckley PJ, Clegg LJ, Cross AR, Liu X, Voss H, Zheng P (2007) The determinants of Chinese outward foreign direct investment. J Int Bus Stud 38:499-518

Busenitz LW, Gomez C, Spencer JW (2000) Country institutional profiles: Unlocking entrepreneurial phenomena. Acad Manag J 43(5):994-1003

Calabrò A, Campopiano G, Basco R, Pukall T (2017) Governance structure and internationalization of familycontrolled firms: The mediating role of international entrepreneurial orientation. Eur Manag J 35:238-248

Calof JL (1994) The relationship between firm size and export behavior revisited. J Int Bus Stud 25(2):367387

Calvo G, Izquierdo A, Talvi E (2006) Sudden stops and phoenixmiracles in emerging markets. Am Econ Rev 96:405-410

Cardona M, Kretschmer T, Strobel T (2013) ICT and productivity: Conclusions from the empirical literature. Inf Econ Policy 25(3):109-125

Cardoza C, Fornes G, Farber V, Duarte RC, Gutierrez JR (2016) Barriers and public policies affecting the international expansion of Latin American SMEs: Evidence from Brazil, Colombia, and Peru. J Bus Res 69:2030-2039 
Carneiro J, Brenes ER (2014) Latin American firms competing in the global economy. J Bus Res 67:831-836 Casillas JC, Acedo FM (2013) Speed in the internationalization process of the firm. Int J Manag Rev 15:15-29

Casillas JC, Moreno-Menéndez AM (2014) Speed of the internationalization process: The role of diversity and depth in experiential learning. J Int Bus Stud 45(1):85-101

Casillas JC, Moreno AM, Barbero JL (2010) A configurational approach of the relationship between entrepreneurial orientation and growth of family firms. Fam Bus Rev 23(1):27-44

Chan C, Isobe T, Makino S (2008) Which country matters? Institutional development and foreign affiliate performance. Strateg Manag J 29:1179-1201

Chang S-J, Rhee JH (2011) Rapid FDI expansion and firm performance. J Int Bus Stud 42(8):979-994

Chavance B (2008) Formal and informal institutional change: The experience of postsocialist transformation. Eur J Comp Econ 5(1):57-71

Chen YR, Yang C, Hsu SM, Wang W-D (2009) Entry mode choice in China's regional distribution markets: Institution vs. transaction costs perspectives. Ind Mark Manag 38(7):702-713

Chetty S, Campbell-Hunt C (2004) A strategic approach to internationalization: A traditional versus a "bornglobal" approach. J Int Mark 12(1):57-81

Chetty S, Johanson M, Marín OM (2014) Speed of internationalization: Conceptualization, measurement and validation. J World Bus 49(4):633-650

Child J, Hsieh L, El Banana S, Karmowska J, Marinova S, Puthusserry P, Tsai T, Narooz R, Zhang Y (2017) SME international business models: The role of context and experience. J World Bus 52(5):664-679

Ciravegna L, Lopez L, Kundu S (2014) Country of origin and network effects on internationalization: A comparative study of SMEs from an emerging and developed economy. J Bus Res 67(5):916-923

Clarke JE, Tamaschke R, Liesch PW (2013) International experience in international business research: A conceptualization and exploration of key themes. Int J Manag Rev 15:265-279

Coviello NE (2006) The network dynamics of international new ventures. J Int Bus Stud 37(5):713-731

Coviello NE, Jones MV (2004) Methodological issues in international entrepreneurship research. J Bus Ventur 19(4):485-508

Crick D (2009) The internationalisation of born global and international new ventures SMEs. Int Mark Rev 26 $(4 / 5): 453-476$

Crick D, Lindsay V (2015) Service and service-intensive New Zealand internationalizing SMEs: Managers' perceptions of government assistance. Mark Intell Plan 33(3):366-393

Cuervo-Cazurra A, Dau LA (2009) Structural reform and firm exports. Manag Int Rev 49(4):479-507

Cuervo-Cazurra A, Genc M (2008) Transforming disadvantages into advantages: Developing-country MNEs in the least developed countries. J Int Bus Stud 39(6):957-979

Cuervo-Cazurra A, Ciravegna L, Melgarejo M, Lopez L (2017) Home country uncertainty and the internationalization- performance relationship: Building an uncertainty management capability. J World Bus 53(2):209-221

Cui L, Li Y, Li Z (2013) Experiential drivers of foreign direct investment by late-comer Asian firms: The Chinese evidence. J Bus Res 66(12):2451-2459

Cyrino AB, Barcellos EP, Tanure B (2010) International trajectories of Brazilian companies. Int J Emerg Mark 5(3/4):358-376

da Rocha A, Cotta de Mello R, Pacheco H, de Abreu FI (2012) The international commitment of lateinternationalizing Brazilian entrepreneurial firms. Int Mark Rev 29(3):228-252

Danis WM, Chiaburu DS, Lyles MA (2009) The impact of managerial networking intensity and market-based strategies on firm growth during institutional upheaval: A study of small and medium-sized enterprises in a transition economy. J Int Bus Stud 41(2):287-307

Dass P (2000) Relationship of firm size, initial diversification and internationalization with strategic change. J Bus Res 48:135-146

De Haan J, Lundström S, Sturm J-E (2006) Market-oriented institutions and policies and economic growth: A critical survey. J Econ Surv 20(2):157-181

Del Sol P, Kogan J (2007) Regional competitive advantage based on pioneering economic reforms: The case of Chilean FDI. J Int Bus Stud 38:901-927

Deng P, Zhang S (2018) Institutional quality and internationalization of emerging market firms: Focusing on Chinese SMEs. J Bus Res 92:279-289

Deng P, Liu Y, Gallagher V, Wu X (2018) International strategies of emerging market multinationals: A dynamic capabilities perspective. J Manag Organ 26(4):408-425

Deng P, Delios A, Peng MW (2020) A geographic relational perspective on the internationalization of emerging market firms. J Int Bus Stud 51:50-71

Dhanaraj C, Beamish PW (2003) A resource-based approach to the study of export performance. J Small Bus Manag 41(3):242-261 
Diamantopoulos A, Ring A, Schlegelmilch BB, Doberer E (2014) Drivers of export segmentation effectiveness and their impact on export performance. J Int Mark 22(1):39-61

Dickson PH, Weaver KM, Vozikis GS (2013) The impact of the institutional environment on SME internationalization: An assessment of the environmental assumptions of emerging integrated models of internationalization. J Appl Bus Econ 15(3):43-55

Dietz JS, Bozeman B (2005) Academic careers, patents, and productivity: Industry experience as scientific and technical human capital. Res Policy 34(3):349-367

Dikova D, Sahib PR, Van Witteloostuijn A (2010) Cross-border acquisition abandonment and completion: The effect of institutional differences and organizational learning in the international business service industry, 1981-2001. J Int Bus Stud 41(2):223-245

Dillman D (2007) Mail and internet surveys: The tailored design method. Wiley, Hoboken

DiMaggio PJ, Powell WW (1983) The iron cage revisited: Institutional isomorphism and collective rationally in organization field. Am Sociol Rev 18(2):147-160

Dimitratos P, Petrou A, Plakoyiannaki E, Johnson JE (2011) Strategic decision-making processes in internationalization: Does national culture of the focal firm matter? J World Bus 46:194-204

Doh J, Rodrigues S, Saka-Helmhout A, Makhija M (2017) International business responses to institutional voids. J Int Bus Stud 48:293-307

Durmuşoğlu SS, Apfelthaler G, Nayir DZ, Alvarez R, Mughan T (2012) The effect of government-designed export promotion service use on small and medium sized enterprise goal achievement: A multidimensional view of export performance. Ind Mark Manag 41(4):680-691

Easton ST, Walker M (1992) Rating global economic freedom. Fraser Institute, Vancouver

ECLAC (2013) Building SME competitiveness in the European Union and Latin America and the Caribbean. ECLAC, Santiago

Elango B, Pattnaik C (2007) Building capabilities for international operations through networks: A study of Indian firms. J Int Bus Stud 38(4):541-555

Elia S, Kafouros M, Buckley PJ (2020) The role of internationalization in enhancing the innovation performance of Chinese EMNEs: A geographic relational approach. J Int Manag 26:1-20

Estrin S, Prevezer M (2011) The role of informal institutions in corporate governance: Brazil, Russia, India, and China compared. Asia Pac J Manag 28:41-67

Ethiraj SK, Kale P, Krishnan MS, Singh VJ (2005) Where do capabilities come from and how do they matters? A study in the software services industry. Strateg Manag J 26(1):25-45

European Commission (2016) User guide to SME definition. Available at: https://ec.europa.eu/regional_ policy/sources/conferences/state-aid/sme/smedefinitionguide_en.pdf. Accessed 16 Jun 2017

Evangelista F, Mac L (2016) The influence of experience and deliberate learning on SME export performance. Int J Entrep Behav Res 22(6):860-879

Evans JR, Mathur A (2005) The value of online surveys. Internet Res 15(2):195-219

Feldmann H (2017) Economic freedom and human capital investment. J Inst Econ 13(2):421-445

Felzenszetein C, Fuerst S (2018) Guest editorial. Acad Rev Latinoam Adm 31(4):626-632

Fernhaber SS, McDougall-Covin PP, Shepherd DA (2009) International entrepreneurship: Leveraging internal and external knowledge sources. Strateg Entrep J 3:297-320

Ferreira P, Saridakis G (2017) Firm shutdown during the financial and the sovereign debt crises: Empirical evidence from Portugal. Int J Econ Bus 24(2):153-179

Figueira-De-Lemos F, Johanson J, Vahlne J-E (2011) Risk management in the internationalization process of the firm: A note on the Uppsala Model. J World Bus 46:143-153

Filatotchev I, Liu X, Buck T, Wright M (2009) The export orientation and export performance of hightechnology SMEs in emerging markets: The effects of knowledge transfer by returnee entrepreneurs. J Int Bus Stud 40(6):1005-1021

Fletcher M, Prashantham S (2011) Knowledge assimilation processes of rapidly internationalising firms: Longitudinal case studies of Scottish SMEs. J Small Bus Enterp Dev 18:475-501

Fraser Institute (2014) Fraser Institute's annual report, Economic Freedom of the World. Available at: https:/www. fraserinstitute.org/sites/default/files/economic-freedom-of-the-world-2014-rev.pdf. Accessed 16 Jun 2017

Freeman S, Edwards R, Schroder B (2006) How smaller born-global firms use networks and alliances to overcome constraints to rapid internationalization. J Int Mark 14(3):33-63

Ganotakis P, Love JH (2012) Export propensity, export intensity and firm performance: The role of the entrepreneurial founding team. J Int Bus Stud 43:693-718

Gao GY, Murray JY, Kotabe M, Lu J (2010) A strategy tripod perspective on export behaviors: Evidence from domestic and foreign firms based in an emerging economy. J Int Bus Stud 41(3):377-396

Gaur AS, Ma X, Ding Z (2018) Home country supportiveness unfavorableness and outward foreign direct investment from China. J Int Bus Stud 49(3):324-325 
GCR (2017) Global Competitiveness Report 2017-2018. Available at: http:/www3.weforum.org/docs/ GCR2017-2018/05FullReport/TheGlobalCompetitivenessReport2017\%E2\%80\%932018.pdf. Accessed 28 July 2019

GEP (2019) Global Economic Prospects: Heightened tensions, subdued investment - a World Bank Group Flagship Report. Available at: https:/documents.worldbank.org/en/publication/documents-reports/ documentdetail/541011559679035492/global-economic-prospects-june-2019-heightened-tensionssubdued-investment. Accessed 31 Oct 2019

Gil-Barragan JM, López-Sánchez MJ (2021) The fast lane of internationalization of Latin American SMEs: A location-based approach. Sustainability 13(3162):1-20

Giovannetti G, Ricchiuti G, Velucchi M (2011) Size, innovation and internationalization: A survival analysis of Italian firms. Appl Econ 43(12):1511-1520

Grant RM (1996) Prospering in dynamically-competitive environments: Organizational capability as knowledge integration. Organ Sci 7(4):375-387

Grant RM (2010) Contemporary strategy analysis: Text only. Wiley, Chichester

Greenwood R, Raynard M, Kodeih F, Micelotta ER, Lounsbury M (2011) Institutional complexity and organizational responses. Acad Manag Ann 5:317-371

Grégoire DA, Barr PS, Shepherd DA (2010) Cognitive processes of opportunity recognition: The role of structural alignment. Organ Sci 21:413-431

Gwartney J, Lawson R, Hall J (2012) Economic freedom dataset. Published in Economic freedom of the world: 2012 annual report. Fraser Institute, Vancouver

Hall JC, Lawson RA (2014) Economic freedom of the world: An accounting of the literature. Contemp Econ Policy 32:1-19

Harzing A-W, Reiche BS, Pudelko M (2013) Challenges in international survey research: A review with illustrations and suggested solutions for best practice. Eur J Int Manag 7(1):112-134

Heritage Foundation (2015) 2015 Index of Economic Freedom: Promoting Economic Opportunity and Prosperity. The Heritage Foundation and Dow Jones \& Company, Inc. U.S.A. Available at: https:// www.heritage.org/index/pdf/2015/book/Index_2015.pdf. Accessed 31 May 2016

Herrera Bernal SM, Burr C, Johnsen RE (2002) Competitor networks: International competitiveness through collaboration: The case of small freight forwarders in the high-tech forwarder network. Int J Entrep Behav Res 8(5):239-253

Hilmersson M (2014) Small and medium-sized enterprise internationalisation strategy and performance in times of market turbulence. Int Small Bus J 23(4):386-400

Hilmersson M, Johanson M (2016) Speed of SMEs internationalization and performance. Manag Int Rev 56: 67-94

Hitt MA, Ahlstrom D, Dacin MT, Levitas E, Svobodina L (2004) The institutional effects on strategic alliance partner selection in transition economies: China vs. Russia. Organ Sci 15:173-185

Hitt MA, Li D, Xu K (2016) International strategy: From local to global and beyond. J World Bus 51(1):58-73

Hollender L, Zapkau FB, Schwens C (2017) SME foreign market entry mode choice and foreign venture performance: The moderating effect of international experience and product adaptation. Int Bus Rev 26 (2):250-263

Hong J, Wang C, Kafouros M (2015) The role of state in explaining the internationalization of emerging market enterprises. Br J Manag 26:45-62

Hoskisson RE, Wright M, Filatotchev I, Peng MW (2013) Emerging multinationals from mid-range economies: The influence of institutions and factor markets. J Manag Stud 50(7):1295-1321

Huang Y, Xie E, Li Y, Reddy K (2017) Does state ownership facilitate outward FDI of Chinese SOEs? Int Bus Rev 26(1):176-188

Javalgi RRG, Todd PR (2011) Entrepreneurial orientation, management commitment, and human capital: The internationalization of SMEs in India. J Bus Res 64(9):1004-1010

Javalgi RG, Todd P, Granot E (2011) The internationalization of Indian SMEs in B-to-B markets. J Bus Ind Mark 26(7):542-548

Johanson J, Vahlne J-E (1990) The mechanism of internationalisation. Int Mark Rev 7(4):11-23

Johanson J, Vahlne J-E (1977) The internationalization process of the firm - a model of knowledge development and increasing foreign market commitments. J Int Bus Stud 8(1):23-32

Jones MV, Casulli L (2014) International entrepreneurship: Exploring the logic and utility of individual experience through comparative reasoning approaches. Entrepreneurship Theory and Practice 38(1):4569

Jones MV, Coviello N, Tang YK (2011) International entrepreneurship research (1989-2009): A domain ontology and thematic analysis. J Bus Ventur 26(6):632-659 
Jormanainen I, Koveshnikov PCA (2012) International activities of emerging market firms. Manag Int Rev 52: 691-725

Kabongo JD, Okpara JO (2019) Timing and speed of internationalization: Evidence from African banks. J Bus Res 102:12-20

Karabegovic A, McMahon F (2005) Economic freedom of North America: 2005 annual report. The Fraser Institute, Vancouver

Ketkar S, Acs ZJ (2013) Where angels fear to tread: Internationalization of emerging country SMEs. J Int Entrep 11(3):201-219

Khoury TA, Peng MW (2011) Does institutional reform of intellectual property rights lead to more inbound FDI? Evidence from Latin America and the Caribbean. J World Bus 46:337-345

Kirzner IM (1997) Entrepreneurial discovery and the competitive market process: An Austrian approach. J Econ Lit 35:60-85

Kiss AN, Danis WM (2008) Country institutional context, social networks, and new venture internationalization speed. Eur Manag J 26(6):388-399

Kiss AN, Danis WM, Cavusgil TS (2012) International entrepreneurship research in emerging economies: A critical review research agenda. J Bus Ventur 27(2):266-290

Knight GA, Kim D (2009) International business competence and the contemporary firm. J Int Bus Stud 40 (2):255-273

Knight GA, Liesch PW (2016) Internationalization: From incremental to born global. J World Bus 51(1):93102

Kor YY, Misangyi VF (2008) Outside directors' industry-specific experience and firms' liability of newness. Strateg Manag J 29(12):1345-1355

Kostova T, Hult TM (2016) Meyer and Peng's 2005 article as a foundation for an expanded and refined international business research agenda: Context, organizations, and theories. J Int Bus Stud 47(1):23-32

Laantia R, Gabrielsson M, Gabrielsson P (2007) The globalization strategies of business-to-business born global firms in the wireless technology industry. Ind Mark Manag 36(8):1104-1117

Langseth H, O’Dwyer M, Arpa C (2016) Forces influencing the speed of internationalisation: An exploratory Norwegian and Irish study. J Small Bus Enterp Dev 23(1):122-148

Laperrière A, Spence M (2015) Enacting international opportunities: The role of organizational learning in knowledge-intensive business services. J Int Entrep 13:212-241

Laufs K, Schwens C (2014) Foreign market entry mode choice of small and medium-sized enterprises: A systematic review and future research agenda. Int Bus Rev 23:1109-1126

Lecler CJ, Kinghorn J (2014) Dynamic capabilities, expert and entrepreneurial learning. S Afr J Bus Manag 45 (2):65-82

Liesch P, Welch L, Buckley P (2011) Risk and uncertainty in internationalisation and international entrepreneurship studies. Manag Int Rev 51(6):851-873

Lindsay A, Rod M, Ashill N (2017) Institutional and resource configurations associated with different SME foreign market entry modes. Ind Mark Manag 66:130-144

LiPuma JA, Newbert SL, Doh JP (2013) The effect of institutional quality on firm export performance in emerging economies: A contingency model of firm age and size. Small Bus Econ 40:817-841

Loane S, Bell J (2006) Rapid internationalization among entrepreneurial firms in Australia, Canada, Ireland and New Zealand: An extension to the network approach. Int Mark Rev 23:467-485

Lopez L, Kundu S, Ciravegna L (2009) Born global or born regional? Evidence from an exploratory study in the Costa Rican software industry. J Int Bus Stud 40:1228-1238

Lu J, Beamish P (2001) The internationalization and performance of SMEs. Strateg Manag J 22(6/7):565-586

Luo Y (2003) Industrial dynamics and managerial networking in an emerging market: The case of China. Strateg Manag J 24(13):1315-1327

Luo Y, Tung RL (2007) International expansion of emerging market enterprises: A springboard perspective. J Int Bus Stud 38(4):481-498

Luo Y, Wang SL (2012) Foreign direct investment strategies by developing country multinational: A diagnostic model for home country effects. Glob Strateg J 2(3):244-261

Madsen TK (2013) Early and rapidly internationalizing ventures: Similarities and differences between classifications based on the original international new venture and born global literatures. J Int Entrep 11(1):65-79

Madsen TK, Servais P (1997) The internationalization of born globals: An evolutionary process? Int Bus Rev 6(6):561-583

Malamud C (2018) Why does Latin America matter? Elcano Royal Institute. Report 22, available at: http:// www.realinstitutoelcano.org/wps/wcm/connect/508f77cc-f90e-42db-89e6-344155289971/informe- 
elcano-22-why-does-latin-americamatter.pdf?MOD=AJPERES\&CACHEID=508f77cc-f90e-42db-89e6344155289971. Accessed 15 April 2019

Martin SL, Javalgi RG (2016) Entrepreneurial orientation, marketing capabilities and performance: The moderating role of competitive intensity on Latin American International New Ventures. J Bus Res 69: 2040-2051

McDougall P, Shane S, Oviatt BM (1994) Explaining the formation of international new ventures: The limits of theories from international business research. J Bus Ventur 9(6):469-487

McDougall P, Oviatt B, Shrader R (2003) A comparison of international and domestic new ventures. J Int Entrep 1:59-82

Mesquita LF, Lazzarini SG (2008) Horizontal and vertical relationships in developing economies: Implications for SMEs' access to global markets. Acad Manag J 51:359-380

Meyer KE, Peng MW (2005) Probing theoretically into Central and Eastern Europe: Transactions, resources, and institutions. J Int Bus Stud 36(6):600-621

Meyer KE, Estrin S, Bhaumik SK, Peng MW (2009) Institutions, resources, and entry strategies in emerging economies. Strateg Manag J 30(1):61-80

Michailova S, Wilson H (2008) Small firm internationalization through experiential learning: The moderating role of socialization tactics. J World Bus 43(2):243-254

Mike WP, Sunny LS, Brian P, Hao C (2009) The institution-based view as a third leg for a strategy tripod. Acad Manag Perspect 23(3):63-81

Mittelstaedt JD, Harben GN, Ward WA (2003) How small is too small? Firm size as a barrier to exporting from the United States. J Small Bus Manag 41(1):68-84

Mohr A, Batsakis G (2014) Intangible assets, international experience and the internationalisation speed of retailers. Int Mark Rev 31(6):601-620

Montocelli JM, Calixto CV, de Vasconcellos SL, Garrido IL (2017) The influence on formal institutions on the internationalization of companies in an emerging country. Rev Bus Manag 19(56):358-374

Mourougane A (2012) Promoting SME development in Indonesia. Paris: Organisation for Economic Cooperation and Development (OECD) Retrieved from http://search.proquest.com/docview/ 1115098492? accountid=13380. Accessed 19 Jun 2017

Mudalige D, Ismail NA, Abdul Malek M (2019) Exploring the role of individual level and firm level dynamic capabilities in SMEs' internationalization. J Int Entrep 17:41-74

Mudambi R, Navarra P (2002) Institutions and international business: A theoretical overview. Int Bus Rev 11 (6):635-646

Musteen M, Francis J, Datta DK (2010) The influence of international networks on internationalization speed and performance: A study of Czech SMEs. J World Bus 45:197-205

Musteen M, Datta DK, Butts MM (2014) Networks and foreign market knowledge facilitate SMEs internationalization? Evidence from the Czech Republic. Entrepreneurship Theory and Practice 38(4):749-774

Narooz R, Child J (2017) Networking responses to contrasting levels of institutional void: A comparison of internationalizing SMEs in Egypt and the UK. Int Bus Rev 26(4):683-696

Nelson RR, Winter S (1982) An evolutionary theory of economic change. Harvard University Press, Cambridge

Ngo VD, Janssen F, Falize M (2016) An incentive-based model of international entrepreneurship in emerging and transition economies. J Int Entrep 14:52-74

North D (1990) Institutions, institutional change, economic performance. Cambridge University Press, Cambridge Organization of American States (OAS)

Nowiński W, Rialp A (2013) Drivers and strategies of international new ventures from a Central European transition economy. J East Eur Manag Stud 18(2):191-231

Nuhu NS, Owens M, McQuillan D (2021) International entrepreneurship from emerging to developed markets: An institutional perspective. Int Mark Rev 38(3):453-486

Nummela N, Saarenketo S, Puumalainen K (2004) Attitude towards internationalization - a prerequisite for successful internationalization? Can J Adm Sci 21(1):51-64

Oehme M, Bort S (2015) SME internationalization modes in the German biotechnology industry: The influence of imitation, network position, and international experience. J Int Bus Stud 46:629-655

Office of the United States Trade Representative (2015) 2015 Trade Policy Agenda and 2014 Annual Report of the President of the United States on the Trade Agreements Program. Available at: https:/ustr.gov/ sites/default/files/2015\%20AR\%20Compiled\%20FINAL_0.pdf. Accessed 16 May 2018

Olejnik E, Swoboda B (2012) SMEs' internationalisation patterns: Descriptive, dynamics and determinants. Int Mark Rev 29(5):466-495

Onkelinx J, Manolova TS, Edelman L (2016) Human capital and SME internationalization: Empirical evidence from Belgium. Int Small Bus J 34(6):818-837 
Oura MM, Zilber SN, Lopes EL (2016) Innovation capacity, international experience and export performance of SMEs in Brazil. Int Bus Rev 25:92-932

Oviatt BM, McDougall PP (1994) Toward a theory of international new ventures. J Int Bus Stud 25(1):45-64

Oviatt BM, McDougall PP (2005) Defining international entrepreneurship: Modelling the speed of internationalization. Entrep Theory Pract 29(5):537-554

Paul J, Gupta P (2014) Process and intensity of internationalization of IT firms - evidence from India. Int Bus Rev 23(3):594-603

Peiris IK, Akoorie ME, Sinha P (2012) International entrepreneurship: A critical analysis of studies in the past two decades and future directions for research. J Int Entrep 10(4):279-234

Pellegrino JM, McNaughton RB (2017) Beyond learning by experience: The use of alternative learning processes by incrementally and rapidly internationalizing SMEs. Int Bus Rev 26:614-627

Peng MW (2003) Institutional transitions and strategic choices. Acad Manag Rev 28(2):275-296

Peng MW, Wang DYL, Jiang Y (2008) An institution-based view of international business strategy: A focus on emerging economies. J Int Bus Stud 39(5):920-936

Penrose E (1959) The theory of the growth of the firm. Basil Blackwell, London

Pino C, Flezensztein C, Chetty S (2019) Institutional knowledge in Latin American SMEs. J Small Bus Manag 59(4):648-674

Puthusserry P, Khan Z, Knight G, Miller K (2020) How do rapidly internationalizing SMEs learn? Exploring the link between network relationships, learning approaches and post-entry growth of rapidly Internationalizing SMEs from Emerging Markets. Manag Int Rev 60(4):515-542

Ramamurti R (2004) Developing countries and MNEs: Extending and enriching the research agenda. J Int Bus Stud 35(4):277-283

Ramamurti R, Doh J (2004) Rethinking foreign infrastructure investment in developing countries. J World Bus 39(2):151-283

Ramamurti R, Singh JV (2009) Emerging multinationals from emerging markets. Cambridge University Press, Cambridge

Rašković M, Dikova D, McDougall-Covin TP (2020) International business with Central and Eastern Europe: From tyranny of history to revisited laboratories of learning. J Bus Res 108:417-420

Reuber AR, Fischer E (1997) The influence of the management team's international experience on the internationalization behaviors of SMEs. J Int Bus Stud 28(4):807-825

Reuber AR, Fischer E (2002) Foreign sales and small firm growth: The moderating role of the management team. Entrepreneurship Theory and Practice 27:29-45

Rialp A, Rialp J, Knight G (2005) The phenomenon of early internationalizing firms: What do we know after a decade (1993-2003) of scientific inquiry? Int Bus Rev 14:147-166

Rugman A (1981) Inside the multinationals: The economics of internal markets. Palgrave Macmillan, New York

Sahaym A, Nam D (2013) International diversification of the emerging-market enterprises: A multi-level examination. Int Bus Rev 22:421-436

Sapienza HJ, Autio E, George G, Zahra SA (2006) A capabilities perspective on the effects of early internationalization on firm survival and growth. Acad Manag Rev 31(4):914-933

Schueffel P, Amann W, Herbolzheimer E (2011) Internationalization of new ventures: Tests of growth and survival. The Multinational Business Review 19(4):376-403

Schwens C, Kabst R (2009) How early opposed to late internationalizers learn: Experience of others and paradigms of interpretation. Int Bus Rev 18:509-522

Sharma P, Luk S, Cardinali S (2018) Challenges and opportunities for marketers in the emerging markets. J Bus Res 86:210-216

Shinkle GA, Kriauciunas AP (2010) Institutions, size and age in transition economies: Implications for export growth. J Int Bus Stud 41(2):267-286

Sol Patricio D, Kogan J (2007) Regional competitive advantage based on pioneering economic reforms: The case of Chilean FDI. J Int Bus Stud 38(6):901-927

Sousa CMP, Martínez-López FJ, Coelho F (2008) The determinants of export performance: A review of the research in the literature between 1998 and 2005. Int J Manag Rev 10:343-374

Stalk G, Hout TM (1990) Competing against time: How time-based competition is reshaping global markets. Free Press, New York

Stoian C, Mohr A (2016) Outward foreign direct investment from emerging economies: Escaping home country regulative voids. Int Bus Rev 25(5):1124-1135

Storey DJ (1994) Understanding the small business sector. Routledge, London

Sun LS, Peng MW, Lee RP, Tan W (2015) Institutional open access at home and outward internationalisation. J World Bus 50:234-246 
Swaminathan A (1996) Environmental conditions at founding and organizational mortality: A trial-by-fire model. Acad Manag J 39:1350-1377

Tang J, Tang Z, Katz JA (2014) Proactiveness, stakeholder-firm power difference, product safety and quality of Chinese SMEs. Entrepreneurship Theory and Practice 38(5):1129-1157

Teece D (2016) Dynamic capabilities and entrepreneurial management in large organizations: Toward a theory of the (entrepreneurial) firm. Eur Econ Rev 86:202-216

Teixeria AAC, Coimbra C (2014) The determinants of the internationalization speed of Portuguese University spin-offs: An empirical investigation. J Int Entrep 12:270-308

Thai MTT, Chong LC (2008) Born-global: The case of four Vietnamese SMEs. J Int Entrep 6(2):72-100

Wagner J (2001) A note on the firm size-export relationship. Small Bus Econ 17:229-237

Wang CQ, Hong JJ, Kafouros M, Boateng A (2012) What drives outward FDI of Chinese firms? Testing the explanatory power of three theoretical frameworks. Int Bus Rev 21:425-438

Wernerfelt B (1984) A resource-based view of the firm. Strateg Manag J 52(2):171-180

West G, Bamford C, Marsden J (2008) Contrasting entrepreneurial economic development in emerging Latin American economies: Applications and extensions of resource-based theory. Entrepreneurship Theory and Practice 32:15-36

Wilkinson T, Brouthers LE (2006) Trade promotion and SME export performance. Int Bus Rev 15(3):233252

Wood E, Khavul S, Perez-Nordtvedt L, Prakhya S, Velarde Dabrowski R, Zheng C (2011) Strategic commitment and timing of internationalization from emerging markets: Evidence from China, India, Mexico, and South Africa. J Small Bus Manag 49(2):252-282

Wright M, Filatotchev I, Hoskisson R, Peng M (2005) Strategy research in emerging economies: Challenging the conventional wisdom. J Manag Stud 42(1):1-34

Xu D, Meyer KE (2013) Linking theory and context: 'Strategy research in emerging economies' after Wright et al. (2005). J Manag Stud 50(7):1322-1346

Yamakawa Y, Peng MW, Deeds DL (2008) What drives new ventures to internationalize from emerging to developed economies? Entrep Theory Pract 32(1):59-82

Yamakawa Y, Khavul S, Peng MW, Deeds D (2013) Venturing from emerging economies. Strateg Entrep J 7 (3):181-196

Yang MM, Li T, Wang Y (2020) What explains the degree of internationalization of early-stage entrepreneurial firms? A multilevel study on the joint effects of entrepreneurial self-efficacy, opportunitymotivated entrepreneurship, and home country institutions. J World Bus 55(6):101-114

Yiu DW, Lau C, Bruton GD (2007) International venturing by emerging economy firms: The effects of firm capabilities, home country networks, and corporate entrepreneurship. J Int Bus Stud 38(4):519-540

Zahra SA (2004) A theory of international new ventures: A decade of research. J Int Bus Stud 36(1):20-28

Zahra SA, Garvis DM (2000) International corporate entrepreneurship and firm performance: The moderating effect of international environmental hostility. J Bus Ventur 49(1):132-142

Zahra SA, George G (2002) International entrepreneurship: The current status of the field and future research agenda. In: Hitt M, Ireland D, Sexton D, Camp M (eds) Strategic entrepreneurship: Creating an integrated mindset. Blackwell Publishers, Malden, pp 255-288

Zahra SA, Matherne BT, Carleton JM (2003) Technological resource leveraging and the internationalization of new ventures. J Int Entrep 1(2):163-186

Zander I, McDougall-Covin P, Rose EL (2015) Born globals and international business: Evolution of a field of research. J Int Bus Stud 46(1):27-35

Zhang X, Ma X, Wang Y, Li X, Huo D (2016) Entrepreneurial orientation, social capital, and the internationalization of SMEs: Evidence from China. Int Bus Rev 25:522-534

Zhang M, Gao Q, Cho HS (2017) The effect of sub-national institutions and international entrepreneurial capability on international performance of export-focused SMEs: Evidence from China and South Korea. J Int Entrep 15(1):85-110

Zhou L, Wu A (2014) Earliness of internationalization and performance outcomes: Exploring the moderating effects of venture age and international commitment. J World Bus 49(1):132-142

Zucchella A, Palamara G, Denicolai S (2007) The drivers of the early internationalization of the firm. J World Bus 42:268-280

Publisher's note Springer Nature remains neutral with regard to jurisdictional claims in published maps and institutional affiliations. 